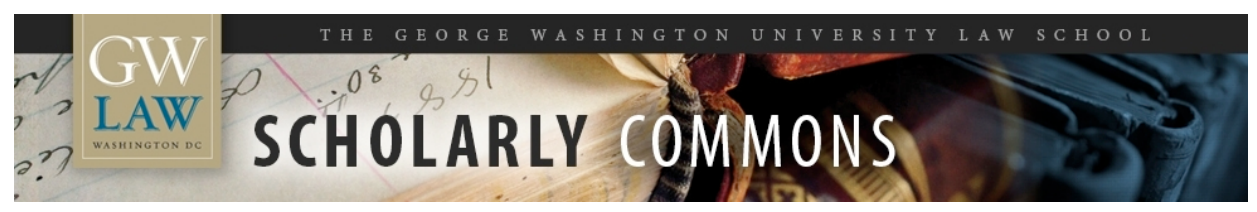

\title{
Postures of Judging: An Exploration of Judicial Decisionmaking
}

Daniel J. Solove

George Washington University Law School, dsolove@law.gwu.edu

Follow this and additional works at: https://scholarship.law.gwu.edu/faculty_publications

Part of the Law Commons

\section{Recommended Citation}

Daniel J. Solove, Postures of Judging: An Exploration of Judicial Decisionmaking, 9 Cardozo Stud. L. \& Literature 173 (1997).

This Article is brought to you for free and open access by the Faculty Scholarship at Scholarly Commons. It has been accepted for inclusion in GW Law Faculty Publications \& Other Works by an authorized administrator of Scholarly Commons. For more information, please contact spagel@law.gwu.edu. 


\title{
Postures of Judging: An Exploration of Judicial Decisionmaking
}

\section{By}

\author{
Daniel J. Solove* \\ 9 Cardozo Studies in Law \& Literature 173 (1997) \\ (C) 1997 by the Yeshiva University; Daniel J. Solove
}

\begin{abstract}
This Article critiques Ronald Dworkin's answer to the question of fit: how judges reconcile general legal rules with particular situations. Dworkin's heavy focus on legal principles under-emphasizes the importance of facts in judicial decisionmaking. Exploring how judges approach the question of fit from a more literary perspective, the Article examines the "posture" of a judge - a judge's physical and temporal position in relation to the cases she adjudicates, a position which affects the level of generality with which a judge perceives the facts of a case and directly influences a judge's toleration of imprecision in fit between general propositions and concrete cases. Postures provide a descriptive account of aspects of our legal experience that Dworkin's principled jurisprudence cannot explain. The Article focuses on Fyodor Dostoyevsky's The Brothers Karamazov to illustrate how a multiplicity of similar yet distinct postures are shaped and how they relate to each other. Through a comparison of law and literature, the Article describes how literature grapples with similar questions as law, and how literature can instruct us about the successes and failures of certain postures.
\end{abstract}

No elaboration of statute law can forestall variant cases and the need of interpretation ad hoc. Moral and legal schemes that attempt the impossible in the way of definite formulation compensate for explicit strictness in some lines by implicit looseness in others. The only truly severe code is the one that forgoes codification, throwing responsibility for judging each case upon the agents concerned, imposing upon them the burden of discovery and adaptation.

$$
\text { -- John Dewey }{ }^{1}
$$

\footnotetext{
* I am greatly indebted to Naomi Lebowitz and Judge Guido Calabresi. They have both been tremendous sources of wisdom, and my many enlightening conversations with them have helped shape the ideas in this Article. Paul Gewirtz, Paul Kahn, Michael Sullivan, and Richard Weisberg provided immeasurable criticism and advice on the manuscript. Finally, I would like to thank Mark Tunick as well as the participants of the Law and Humanities Institute meeting where I delivered this paper for their insights and comments.

${ }^{1}$ John Dewey, Human NATURE AND Conduct, Jo Ann Boydston, ed. (Carbondale: Southern Illinois University Press, 1922; 1988 ed.), p. 74.
} 


\section{Introduction}

"How do courts decide difficult or controversial lawsuits?" ${ }^{2}$ asks Ronald Dworkin, one of the leading figures in modern American jurisprudence. Dworkin's question goes to the heart of judging. Specifically, one of the central issues in jurisprudence concerns how judges deal with the "gaps" between abstract rules and concrete cases. This is what I refer to as the "question of fit": How should judges decide cases in which legal rules do not seem to fit a particular situation? In a series of books, chiefly Taking Rights Seriously, A Matter of Principle, and Law's Empire, Professor Dworkin has developed a theory that attempts to explain how judges should resolve these cases, which he labels "hard cases." ${ }^{3}$ Dworkin argues that law supplies a determinate answer in hard cases. For Dworkin, judging is the practice of legal argumentation, the activity of solving disputes by constructing the best argument from general legal propositions (rules and principles). "Legal practice, unlike many other social phenomena, is argumentative," Dworkin observes. "Every actor in the practice understands that what it permits or requires depends upon the truth of certain propositions that are given sense only by and within the practice; the practice consists in large part in deploying and arguing about these propositions." (LE 13) Descriptively, Dworkin argues that law consists of principles, which are abstract moral standards of differing weights and directions. In hard cases, judges search for principles which will fill the gaps between legal rules and particular situations. Normatively, Dworkin argues that judges should emulate Hercules, a super-human judge who attempts to understand the law as a coherent set of principles. Since principles have different weights and can pull in different directions, it remains the task of the judge to determine the net vector of the principles as applied to particular cases.

In this Article, I shall argue that Dworkin's principles do not fill the gaps between general rules and particular cases, for principles, despite their distinctness from rules, are still a form of abstraction. Judging cannot adequately be explained as the activity of constructing the best legal arguments, and Dworkin's heavy focus on legal propositions underemphasizes the importance of facts in judicial decisionmaking. I will illustrate that literature can play a critical role in understanding how judges approach the question of fit. Specifically, I will concentrate on one work of literature, Dostoyevsky's The Brothers Karamazov, and the insights it can bring into this jurisprudential debate.

In Part II, I will show how Dworkin's account of judging does not explain how judges grapple with the question of fit. Dworkin frames this question as one involving almost exclusively the interpretation of propositions of law (rules, standards, principles, etc.). However, I shall argue that the question of fit involves the relationship between factual situations and general legal propositions. Judging is not centrally about legal argument but is quite concerned with the complex interactions between the facts of particular situations and abstract rules and principles. The relationship between facts and general propositions cannot be explained by reference to principles alone.

\footnotetext{
${ }^{2}$ Ronald DwORKIn, TAKING Rights SERIOUSLY (Cambridge: Harvard University Press, 1978), p. 3 (further citations in the text as TRS).

${ }^{3}$ See RONALD DWORKIn, LAW's EMPIRE (Cambridge: Harvard University Press, 1986)(citations in the text as LE); RonAld Dworkin, A MATTER OF PrInCIPLE (Cambridge: Harvard University Press, 1985)(citations in the text as MP); Ronald DWORKIN, TAKING RightS SERIOUSLY, supra note 2. Professor Dworkin has elaborated aspects of his theory in several other books and articles. However, in this Article, I shall center my discussion around these three books which present the most comprehensive elaboration of his jurisprudence.
} 
In Part III, I shall explore how judges approach the question of fit from a more literary perspective. I will examine what I refer to as the "posture" of a judge--her physical and mental position in relation to the cases she decides. Postures provide a descriptive account of how judges apply general legal propositions to concrete factual situations. In this Part, I will explain the importance of a judge's physical and temporal position in relation to the cases she adjudicates. This position influences a judge's perspective (the level of generality with which a judge perceives the facts of a case) as well as a judge's toleration of imprecision (the degree of imprecision in fit between general propositions and concrete cases). Although postures are hardly ever stable, they are not completely fickle and unpredictable. By examining how postures move and interact when confronted with new factual situations, we can enhance our understanding of how and why postures change. I will use examples from The Brothers Karamazov, ${ }^{4}$ which brilliantly illustrates how a multiplicity of similar yet distinct postures are shaped and how they relate to each other. Ultimately, I hope to show how postures provide a descriptive account of aspects of our legal experience that Dworkin's principled jurisprudence cannot explain.

In Part IV, I will turn to the normative questions: how postures can be evaluated and critiqued. Through a comparison of law and literature, I will show the constraints, endemic to the legal experience, that affect judge's postures. More importantly, I will illustrate how literature grapples with similar questions as law, and how literature can instruct us about the successes and failures of certain postures. There are meaningful normative arguments that can be made about judging-specifically, in terms of which postures are better or worse at engaging the difficult tensions inherent in judging.

\section{The Question of Fit}

Jurisprudence has long grappled with the question of fit: how judges reconcile general legal rules with particular situations. ${ }^{5}$ The question of fit involves the degree of imprecision in fit between general legal propositions and individual cases that judges recognize and tolerate. Political and legal philosophers have approached the question of fit in the contexts of common law precedents, constitutional provisions, and statutes and regulations. As William

\footnotetext{
${ }^{4}$ All quotes from The Brothers Karamazov are from the Richard Pevear and Larissa Volokhonsky translation (Vintage Classics edition, 1990)(further citations in the text as BK). Although The Brothers Karamazov is frequently mentioned on law and literature canon lists, only a handful of legal works have actually examined it in depth. The most detailed and sophisticated examination of legal themes in the novel is Richard H. WeISBERG, THE FAILURE OF THE WORD (New Haven: Yale University Press, 1984), pp. 55-81. See also Richard A. POSNER, LAW AND Literature: A MisUNDERSTOOD RELATION (Cambridge: Harvard University Press, 1988), pp. 166-171; Saul Touster, "Law at the Bar of Literature: Some Aspects of Dostoyevsky and Brecht," 5 ALSA Forum 13 (1981); J. Neville Turner, "Dostoyevsky--The Trial in Brothers Karamazov," 8 University of Tasmania Law Review 62 (1984).

5 See, e.g., Aristotle, Nicomachean Ethics, Terence Irwin, trans. (Indianapolis: Hackett Publishing Company, 1985), 1138a, 22-24 (discussing the question of fit in terms of the need for exceptions to general laws in cases of apparent injustice); WILLIAM BLACKSTONE, COMMENTARIES ON THE LAWS OF ENGLAND, Vol. I (1765; Chicago: University of Chicago Press, 1978), pp. 61-62, 91-92, 1959) (discussing the question of fit in terms of the need for, and dangers of, equity); 4 RosCOE POUND, JURISPRUDENCE $§ 115$, at 9-10 St. Paul: West Publishing Company ("To find a proper mean between a system of rules applied mechanically and a system of completely individualized justice is one of the inherent difficulties of all administration of justice.").
} 
Blackstone framed this issue in regard to statutory interpretation: "Since in laws all cases cannot be foreseen or expressed, it is necessary, that when general decrees of law come to be applied to particular cases, there should be somewhere a power vested of excepting those circumstances, which (had they been foreseen) the legislator himself would have excepted." ${ }^{6}$ In this Part, I will examine how Ronald Dworkin's theory of judging, the most comprehensive and influential theory in contemporary jurisprudence, addresses the question of fit. I will then illustrate the inadequacies of Dworkin's theory in providing a compelling descriptive and normative account of how judges must approach this central question in jurisprudence.

\section{A. Ronald Dworkin's Theory of Judging}

In Taking Rights Seriously, Dworkin launches his theory of judging as a response to the legal positivists, especially the jurisprudence of H.L.A. Hart. Dworkin and Hart differ most explicitly about how judges should adjudicate "hard cases," those that are not covered under a clear rule of law. (TRS 81) In The Concept of Law, Hart argues that

Whichever device, precedent or legislation, is chosen for the communication of standards of behaviour, these, however smoothly they work over the great mass of ordinary cases, will, at some point where their application is in question, prove indeterminate; they will have what has been termed an open texture. ${ }^{7}$

Hart and other legal positivists argue that in hard cases, judges have discretion to decide the case either way. If a case is not clearly covered by a rule or if a rule is vague, then the case cannot be decided according to the law, for "[t]he set of these valid legal rules is exhaustive of 'the law'...." (TRS 17) Cases not clearly covered by rules must be decided by some legal official applying discretion. Discretion constitutes a non-legal grounding for a decision; it involves "reaching beyond the law for some other sort of standard to guide him in manufacturing a fresh legal rule or supplementing an old one." (TRS 17) When judges have discretion, they have the freedom to decide the case according to their own will, intuitions, and values. Thus, according to the positivists, the rule of law does not extend to hard cases.

For Dworkin, however, "even when no settled rule disposes of the case, one party may nevertheless have a right to win." (TRS 81) Dworkin asserts that law directs the outcome of all cases; there are no gaps in the rule of law that occasion the use of individual discretion. Although a particular case may not readily fit under any explicit rules, there exist in the law (in statutes and precedents) moral standards called "principles" which are applicable to the case. According to Dworkin, a principle is "a standard that is to be observed, not because it will advance or secure an economic, political, or social situation deemed desirable, but because it is a requirement of justice or fairness or some other dimension of morality." (TRS 22) When analyzed and applied, principles will govern the outcome of all cases, even hard cases. Principles underpin statutes and precedents; they are the components of arguments in the law. Although they are generalized propositions, principles are dissimilar from rules. While "[r]ules are applicable in an all-or-nothing fashion," (TRS 24) principles "incline a decision one way, though not conclusively, and they survive intact when they do not prevail." (TRS 35) Rules are thus more rigid than principles. "Principles have a dimension that rules do not--the dimension of weight or importance." (TRS 26) Principles all pull in their own ways with their own weights, but the final vector will lead a judge to a decision.

\footnotetext{
${ }^{6} 1$ William BLACKSTONE, COMmentaries supra, note 5 at 61.

${ }^{7}$ H.L.A. HART, THE CONCEPT OF LAW (Oxford: Clarendon Press, 1961), p. 124.
} 
Thus, for Dworkin, principles fill the gaps encountered in hard cases. As a result, "in most hard cases there are right answers to be hunted by reason and imagination." (LE viii-ix)

In Law's Empire, Dworkin explores three conceptions of law-- conventionalism, pragmatism, and law as integrity--and concludes that the third is the most defensible conception. Conventionalism is a conception of precedent; rights emerge from precedents that are legitimate through conventionally accepted methods, and judges must respect established legal conventions. (LE 94, 116) In contrast to conventionalism, which looks to the past, pragmatism focuses on the future. Under a theory of pragmatism, a judge decides what is best for the future. Consistency is not valued for its own sake. (LE 94) A pragmatist looks to precedent only to the extent that the pragmatist values stability as important in a legal system. Pragmatism, according to Dworkin, cannot account for why judges are so concerned with precedents and statutes when they decide hard cases. (LE 159)

Dworkin's theory--law as integrity--combines elements of both conventionalism and pragmatism. A right flows from principles, which can be found in precedent. (LE 94) Integrity is coherence; judges must enforce and apply the law as coherent in principle. (LE 167) Dworkin attacks what he called "checkerboard laws," laws that treat similar cases differently on arbitrary grounds. Checkerboard laws are improper compromises. "We insist on integrity because we believe that internal compromises would deny what is often called 'equality before the law' and sometimes 'formal equality."' (LE 185) The problem with checkerboard solutions is that they run against our instincts for consistency. (LE 82-83) Unlike checkerboard solutions, law as integrity strives for consistency; however, it does not pursue a "narrow consistency" but a broader and more imaginative form of coherence. (LE 220) "Law as integrity asks judges to assume, as far as this is possible, that the law is structured by a coherent set of principles." (LE 243) Thus, when deciding a case, judges must search for principles in the law as a whole, not just the cases that appear to be most on point. (LE 220)

Dworkin illustrates the normative dimension of his theory of judging by describing the judicial approach of Hercules, "an imaginary judge of superhuman intellectual power and patience who accepts law as integrity." (LE 239) When judging an individual case, Hercules conducts an interpretation of the whole of a society's legal practice in order to discover its coherent scheme of principles. Hercules will discern the directions and weights of the principles and judge the case according to their collective guidance.

Hercules' common law jurisprudence is one of precedent. In both A Matter of Principle and Law's Empire, Dworkin analogizes the adjudication of a case to writing a new chapter in a chain novel. (LE 228-238; MP 158-162) Each judge is a novelist, participating in a collaborative creation, attempting to make the chain novel unified and continuous: "Each has the job of writing his chapter so as to make the novel being constructed the best it can be, and the complexity of this task models the complexity of deciding a hard case under law as integrity." (LE 229) Hercules will not blindly follow the holdings of past cases; rather, he will look to the principles which best justify the precedents. (TRS 116) Hercules "must construct a scheme of abstract and concrete principles that provides a coherent justification for all common law precedents and, so far as these are to be justified on principle, constitutional and statutory provisions as well." (TRS 116-117)

Dworkin recognizes that Hercules is an idealized account of judging: "No actual judge could compose anything approaching a full interpretation of all of his community's law at 
once. That is why we are imagining a Herculean judge of superhuman talents and endless time." (LE 245) Dworkin does not intend Hercules to be an accurate descriptive model of how judges actually judge; rather, Hercules represents the ideal form of judging, the model all judges should strive to follow. Moreover, Dworkin's descriptive model of law has a normative component. Dworkin recognizes that we cannot "bring all the discrete rules and other standards... under any single, coherent scheme of principle." (LE 217) Although integrity cannot be enforced perfectly and may not be a precise descriptive match for societal practices, it remains a normative goal to achieve. (LE 217)

\section{B. Facts and Unfilled Gaps}

Dworkin's jurisprudence fails to provide a convincing resolution to the question of fit. Part of the reason for its failure stems from the fact that Dworkin focuses almost exclusively on legal argumentation and does not examine the role of facts in adjudication. Dworkin states that Law's Empire "is about theoretical disagreements in law" and will not focus on disagreements of fact. (LE 11-12) According to Dworkin, "[o]ur most intense disputes about justice- about income taxes, for example, or affirmative action programs-are about the right tests for justice, not about whether the facts satisfy some agreed test in some particular case." (LE 73)

In contrast to Dworkin's assertions, much disagreement in law does not concern the identification of principles but the application of principles to particular cases. Principles are abstract propositions, such as "no one should profit from his own wrong." (LE 20) Of course, there are principles of varying degrees of generality; however, principles cannot be too specific, for they must be able to transcend particular situations and apply more broadly. Questions of applicability cannot be answered only by looking at abstract propositions, for application involves the interaction between general propositions and particular factual situations. According to Justice Holmes famous aphorism: "General propositions do not decide concrete cases. The decision will depend upon a judgment or intuition more subtle than any articulate major premise." 8

A general proposition acquires its meaning through its application, through the particular examples which establish its contours and its borders. ${ }^{9}$ "We have discovered that rules alone, mere forms of words, are worthless," Karl Llewellyn observes, "We have learned that the concrete instance, the heaping up of concrete instances, the present, vital memory of a multitude of concrete instances, is necessary in order to make any general proposition, be it rule of law or any other, mean anything at all." ${ }^{10}$ Through the process of continual application, the meanings of general propositions evolve. While Dworkin's analogy of law to a chain novel provides a helpful account of how judges reconcile their impending legal decisions with previous legal judgments, this analogy only partially captures the evolution of general legal propositions. The central subject of Dworkin's chain novel is law, not facts, and for Dworkin, the critical issue of "fit" is between new legal decisions and the existing body of legal rules and principles: "[T]he argument turns on which rules or principles of law 'underlie' the related decisions of other judges in the past." (MP 159)

${ }^{8}$ Lochner v. New York, 198 U.S. 45, 76 (1905) (Holmes, J. dissenting).

${ }^{9}$ See Oliver Wendell Holmes, "Codes and the Arrangement of Law," 5 Am. Law Review 1 (1870) ("It is the merit of the common law that it decides the case first and determines the principle afterwards.").

${ }^{10}$ Karl N. Llewellyn, The Bramble Bush: On Our Law and its Study (New York; Oceana Publications, Inc., 1960), p. 2. 
However, the argument often turns not on which general legal propositions underlie prior related decisions but on what degree certain prior decisions are related to the present case. This determination involves factual interpretation, and the way judges interpret facts cannot be understood by solely focusing on general legal propositions. Of course, the interpretation of facts is influenced by the general propositions judges are planning to apply. However, the meaning of general propositions-and the abstract frameworks and models humans use to conceptualize their experiences-are themselves shaped by experiences. ${ }^{11}$ Humans are never equipped with a perfect framework for categorizing experience; as they encounter new experiences, they initially attempt to understand and react with their existing frameworks. But these frameworks are never adequate, and people are constantly faced with experiences that challenge our existing conceptions. In sum, a judge's interpretation of facts and her mental constructs influence and shape each other in a hermeneutical relationship. Individual cases, partly understood and conceptualized on the basis of general propositions, also change and give meaning to these general propositions. ${ }^{12}$

Dworkin, however, believes that cases can be decided on principles alone. Principles transcend the concrete instance, and they are the authority that should control how concrete cases are decided. For example, Dworkin explains how Hercules would decide Brown v. Board of Education. ${ }^{13}$ Hercules would conclude that "state-imposed segregation in education is unconstitutional." (LE 388) Hercules would base his decision on principle; there was a "growing sense [in American society] that racial segregation was wrong in principle, because it was incompatible with decency to treat one race as inherently inferior to another." (LE 388, emphasis added)

But this is a factual, not a principled, determination. At the principled level, one could declare that "people should not be treated as inferior on account of their race." This principle, however, was not really in dispute in Brown. Brown hinged on whether the practice of segregation violated this principle, a determination based on an interpretation of the current factual circumstances, not merely on principles. In fact, the Supreme Court was interpreting the same principle in Plessy v. Ferguson ${ }^{14}$ when it held that segregation was constitutional so long as the facilities were equal (the separate but equal doctrine). The critical difference in these two cases was the Court's conclusion in Brown that segregation in education generates feelings of inferiority among African-Americans. ${ }^{15}$ This conclusion was factual in nature and supported by empirical, psychological, and sociological studies. ${ }^{16}$ In sum, principles alone cannot resolve cases, for the very meaning of the principles is affected and altered by the facts of the cases.

\footnotetext{
11 "The common law does not work from pre-established truths of universal and inflexible validity to conclusions derived from them deductively. Its method is inductive, and it draws its generalizations from particulars." Benjamin N. Cardozo, The Nature of the Judicial Process in M.E. Hall, Ed., Benjamin Nathan Cardozo Selected Essays (New York: Matthew Bender, 1947, 1975), 113-114.

${ }^{12}$ See Llewellyn, BRAmBle BuSh, supra note 10 at 36 ("[A]lthough the outcome in the case may be (and commonly is) a function of the rule laid down, the rule laid down may be (and commonly is) a function of the outcome of the case.").

${ }^{13} 347$ U.S. 483 (1954).

${ }^{14} 163$ U.S. 537 (1896).

15347 U.S. at 494.

${ }^{16} 347$ U.S. at 495 n. 11.
} 
The application of rules and principles is an activity of categorization and classification. ${ }^{17}$ The facts of the case must "fit" under a general proposition, a determination made by analogizing or distinguishing between the instant case and other cases which have previously been found to fit under the proposition. In our system of law, judicial decisionmaking is ad hoc. Judges interpret statutes, precedents, rules, and the Constitution on a case-by-case basis; indeed, the Constitution is not expounded in an orderly philosophical manner, but only when "cases" or "controversies" arise. ${ }^{18}$

However, no two cases are ever identical. According to Aristotle, the "universality of law makes it deficient," ${ }^{19}$ for all abstractions are imperfect simplifications of reality. Although no two cases are exactly alike, the law, for stability and continuity, classifies related cases together under general propositions. Thus, in order to apply rules and precedents, judges must determine whether a case fits, whether the case is similar enough to the other instances in which the general proposition was applicable.

Because any system of general propositions is imperfect, particular cases always arise that seemingly fit into one category, yet, if a judge applied the rules and principles typically applicable to cases in that category, the result would be unjust. One could argue that this injustice should be ignored, since one of the essential principles of justice is treating like cases alike. However, this merely begs the question. Treating like cases alike is a statement of formal justice. It cannot tell a judge how to determine what cases are similar; rather, it merely instructs judges that once they determine that a case is similar to another, both should be decided similarly. Some judges, however, treat certain apparent similarities as given despite manifestations of injustice. In the provocative words of one judge: "[A] rigid adherence to fundamental principles at all times, and a stern insensibility to the results which an unvarying enforcement of those principles may occasionally entail, are the surest, if not the only, means by which stability and certainty in the administration of the law may be secured." ${ }^{20}$ Yet for other judges, potential injustice raises serious questions that the case might not fit into an existing category or under a seemingly applicable legal proposition. Judges who would not apply the applicable legal proposition have often been charged with judicial activism, creating new law rather following existing law. However, this charge mischaracterizes of what is really at issue, for these judges would argue that they are following the law. According to them, they are not manipulating the law to conform to their own ideologies; rather, they believe that the facts of the case present special concerns that suggest that the existing legal propositions are inapplicable:

The argument that making "some distinctions" between what is and what is not absolute under the Constitution is to render us a government of men, not laws, gives too little weight to the fact that it is an essential part of adjudication to draw distinctions, including fine ones, in the process of interpreting the Constitution. ${ }^{21}$

Clearly, it would be incorrect to apply a legal proposition that is not properly applicable to a particular case. "The grossest discrimination can lie in treating things that are different as

\footnotetext{
${ }^{17}$ Professor Cass Sunstein refers to this activity as "analogical reasoning." See CASS R. SUNSTEIN, Legal Reasoning AND Political Conflict (Oxford: Oxford University Press, 1996), p. 62.

${ }^{18}$ U.S. Const. Art. III, $\S 2$.

${ }^{19}$ ARISTOTLE, supra note 5 at $1138 \mathrm{a} 27$.

${ }^{20}$ Demuth v. Old Town Bank, 37 A. 266, 266 (Supreme Ct., Md. 1897).

${ }^{21}$ Walz v. Tax Comm'n, 397 U.S. 664, 679 (1970) (opinion of Burger, C.J.).
} 
though they were alike." 22

Since all general propositions are necessarily an imprecise fit for each unique factual situation, judges must decide what level of imprecision they are willing to tolerate. As Justice Cardozo explained:

"Much of the administration of justice," says Pound," is a compromise between the tendency to treat each case as one of a generalized type of case, and the tendency to treat each case as unique." Each method has its value, and for each in the changes of litigation there will come the hour for use. A wise eclecticism employs them both. ${ }^{23}$

The question of fit cannot be answered merely by examining principles or rules or standards, for it is a question that involves the interpretation not only of law, but also of facts. Both Hart and Dworkin have not adequately approached the question of fit, for their theories share a similar narrow focus on legal propositions (rules and/or principles), relegating facts to the fringes of law's empire. But facts are an essential aspect of law, and exploring how the law interacts with facts is critical to examining how judges approach the question of fit.

\section{Postures}

We may try to see things as objectively as we please. Nonetheless, we can never see them with any eyes except our own.

-- Justice Benjamin N. Cardozo ${ }^{24}$

How do judges categorize concrete factual situations within the existing architecture of the law? As I illustrated in the previous Part, Dworkin does not provide a convincing explanation of how judges grapple with the question of fit. The question of fit concerns how judges understand the factual circumstances of concrete cases as much as it concerns how they approach existing legal rules and principles. In this Part, I will explore from a more literary perspective how judges approach the question of fit. I will argue that judging occurs from a particular posture, a location in time and space. Drawing insights from Dostoyevsky's The Brothers Karamazov, I will examine postures, their characteristics, and their interrelations with other postures. Then, I will sketch a literary jurisprudence of postures. In melding this literary notion of postures into jurisprudence, I aim not to betray the literature or to transform it into philosophy. Rather, I aim to intermingle the two disciplines, to bring them closer together so that they can share their insights with each other.

\section{A. Postures and the Question of Fit}

\section{Judgment Embodied}

When we are too young, we do not judge well; so, also, when we are too old. If we do not think enough, or if we think too much on any matter, we get obstinate and infuriated with it. If one considers one's work immediately after having done it, one is entirely prepossessed in its favor; by delaying too long, one can no longer enter into the spirit of it. So with pictures seen from too far or too near; there is but one exact point which is the

${ }^{22}$ Justice Stewart in Jenness v. Fortsan, 403 U.S. 431, 442 (1971).

${ }^{23}$ Benjamin N. CARdozo, The ParadoXes OF Legal Science In EsSays, at 256

${ }^{24}$ Cardozo, Nature of the Judicial Process, in Essays, supra note 11 at 13. 
true place where from to look at them: the rest are too near, too far, too high, or too low. Perspective determines the point in the art of painting. But who shall determine it in truth and morality? ${ }^{25}$

This passage from Pascal's Pensees raises the essential question: From what perspective shall we judge certain situations? This question suggests that judging involves location. I will refer to the location and perspective from which judging occurs as a judge's "posture." In this Article, I refer to postures not as they are typically, and often pejoratively used: as political "posturing," taking tactical and rhetorical positions on issues to cultivate public favor. In contrast, the postures I discuss allude to a person's genuine position on an issue. Naomi Lebowitz in The Philosophy of Literary Amateurism, elaborates that a person's posture represents her "bearing towards ideas" ${ }^{26}$ as opposed to merely the ideas themselves. Postures involve how a person understands an idea, how different personalities and temperaments think about theories and concepts. In contrast to Dworkin's depiction of his ideal judge, Hercules, who has no personality, no passions, no life experiences, and no intuitions, understanding judging as posture emphasizes the individual making the judgment, situating the judgment within a context and within a body. ${ }^{27}$ This reveals judgment's relationship with the rest of the self--corporeal nature, location in time and space, past experience, anticipated future, perception, and other ideas, thoughts, and desires. How we judge is who we are. Judging concerns the self as much as it concerns the object of judgment, for we shape our world and ourselves through our judgment. Judging is how we evaluate and understand experience, how we engage the world.

\section{The Tension Between Abstraction and Individuation}

It is a judge's posture that explains how she determines what degree of imprecision she will tolerate when applying general propositions to concrete cases. This degree of imprecision can be visualized along a continuum between absolute abstraction (a position that generalizes everything at the broadest level) and absolute individuation (a position in which each object or case is so unique that it is in a class by itself).

Of course, positions of absolute abstraction and absolute individuation are impossible in practice. Judges, then, each adopt some compromise position--a posture--along the continuum between abstraction and individuation. According to Aristotle, this is the essence of being a good judge--adopting a workable compromise between abstraction and individuation. Aristotle argues that a system of general rules is preferable to the discretion of individual judges, yet he recognizes that general rules are imperfect. For Aristotle, judges, acting as guardians of the law, should attempt to rectify any injustices that might arise in certain cases. ${ }^{28}$ Martha Nussbaum observes: "Aristotle speaks of the equity of the flexible

${ }^{25}$ Blaise Pascal, Pensees, No. 21, in Pascal: Selections, Richard H. Popkin, ed. (New York: Macmillan Publishing Company, 1989), pp. 196-197.

${ }^{26}$ NAOMI LeBowitz, The Philosophy OF Literary AMATEURISM (Columbia: University of Missouri Press, 1994), p. 3. I have developed my conception of "postures" from Professor Lebowitz and am greatly indebted to her for her profound insights about literature and philosophy.

${ }^{27}$ Professor J.M. Balkin argues persuasively that legal theorists have often neglected to focus on the legal subject. See J.M. Balkin, "Understanding Legal Understanding: The Legal Subject and the Problem of Legal Coherence," 103 Yale Law Journal 105 (1993).

${ }^{28}$ See ARISTOTLE, supra note 5 at 1138a22-24. William Blackstone expresses a similar notion when he speaks of the need for equity: "[T]here are courts of [equity] established for the benefit of the subject, to correct and soften the rigor of the law, when through its generality it bears to hard in the particular cases." 1 William BlaCKSTONE, COMMENTARIES supra note 5 at 91. 
ruler as the virtue of a good judge. And his idea is that a judge of practical wisdom, rather than being unreflectively subservient to law, will apply it in accordance with his very own ethical judgment, looking attentively at the history and the circumstances of his city as he does so." 29

Proponents of practical wisdom take an Aristotelian posture of judging. Good judging concerns more than mere rule following and syllogistic deduction. Anthony Kronman defines practical wisdom as "a subtle and discriminating sense of how the (often conflicting) generalities of legal doctrine should be applied in concrete disputes. ${ }^{30}$ For Kronman, deliberation has a "bifocal" character, requiring one to focus on the case at close range with sympathy and compassion and also to view the case at a distant perspective with detachment and neutrality. ${ }^{31}$ Although not all judging maintains a moderate Aristotelian posture between abstraction and individuation, all judging occurs from a posture between abstraction and individuation. Yet the number of possible postures approaches infinity, and the scope is vast. To understand judgment, we must explore the intricate negotiations by which these postures are reached.

\section{B. The Multiplicity of Postures in The Brothers Karamazov}

What postures are possible? How and why do judges arrive at certain postures? How do postures navigate the tension between abstraction and individuation? These questions cannot be answered systematically through philosophical explication alone; they must be explored in a more contingent, less universal manner, from all the scraps of experience that compose our existence. We can draw wisdom about postures from numerous sources, and here I will focus heavily on one source: Fyodor Dostoyevsky's The Brothers Karamazov.

The Brothers Karamazov chronicles a murder, investigation, and trial in a small Russian town. Three brothers stand at the core of the novel: Ivan Karamazov, an intellectual expounding radical theories about God and justice; Dimitri Karamazov, a passionate, hot-blooded sensualist; and Alyosha Karamazov, a gentle disciple studying to become a monk. They are brought together in the frenzied events surrounding the murder of their father, Fyodor Karamazov, a disgraceful buffoon who lived a selfish, wanton, and immoral life.

Dostoyevsky's The Brothers Karamazov has often been hailed as one of the greatest novels of ideas. While this characterization of the novel is certainly true, it is only partially accurate, for The Brothers Karamazov is not merely about naked ideas, but about ideas embodied in a panoply of characters. Rather than explore philosophical issues in a systematic way, the novel teems with a horde of personalities, each having a distinctive perspective on similar ideas. Thus, the ideas never exist in their Platonic purity but pulse through the troubled ambivalent minds of the characters, altered and contorted by their individual eccentricities and temperaments. ${ }^{32}$ Ideas, constantly muddled, sullied, bruised,

${ }^{29}$ Martha C. Nussbaum, Love's KNOWLEDge: Essays On Philosophy AND Literature (Oxford: Oxford University Press, 1990), p. 99. For an excellent discussion of Aristotle's thought on generality and particularity, see generally id., at 66-75.

${ }^{30}$ Anthony T. KRONMAN, The Lost Lawyer (Cambridge: Harvard University Press, 1993), p. 21.

${ }^{31} I d$., at 72 .

${ }^{32}$ Milan Kundera notes that Dostoyevsky was "a great thinker only as a novelist," not when he expounded his views like a philosopher in Diary of a Writer. "Once it is part of a novel," Kundera writes, "reflection changes its essence: a dogmatic thought turns hypothetical." MILAN KUNDERA, 
and compromised by the exigencies of experience, spin off into tangents, reconnect and reappear in various forms and combinations. Philosophy and personality intersect and interact in the postures of characters. The Brothers Karamazov illuminates the nature of postures since it so superbly depicts how abstract conceptions relate to the individuals who think about them.

The philosophical themes that dance through the bodies of various personae consist of the most fundamental existential and political questions: the existence of God, the necessity of religious faith for an objective system of morality, the fundaments of human nature, the political structure of the polity. "[W]e green youths," Ivan Karamazov declares, "need first of all to resolve the everlasting questions." (BK 234) Is God's divine justice necessary for the political and social order of humankind? Can human justice (the law) replace divine justice as the underlying basis for moral behavior? Without God, how should society be governed? In the novel, these issues are deeply interrelated and are pondered over by numerous characters in a myriad of interesting permutations.

The novel's themes converge in a more rudimentary question: How should we judge? Judging involves an observation and an evaluation of particular human actions and about human behavior in general. Legal and moral systems, human and divine justice, political and social interaction influence, and are affected by, how we observe and evaluate human conduct. Indeed, Ivan Karamazov's questioning of the adequacy of divine order and justice stem from his judgments about human nature and conduct, and his posture consists of the physical and temporal location from which he observes and evaluates. Like Ivan, each character struggles to maintain a posture of judging, and the narrative of the novel is created out of their interaction.

\section{Polyphony and The Dialogue Between Postures}

The Brothers Karamazov is a novel of divisions. Internal dialogues within postures (the tension between abstraction and individuation) are joined by external dialogues between postures. Mikhail Bakhtin describes Dostoyevsky as the creator of the polyphonic novel. A polyphonic novel is not a dialectic between two adversarial positions, but a horde of different positions of varying strength and intensity, which coexist and interact. ${ }^{33}$ "What unfolds in his works," writes Bakhtin, "is not a multitude of characters and fates in a single objective world, illuminated by a single authorial consciousness; rather a plurality of consciousnesses, with equal rights and each with its own world, combine but are not merged in the unity of the event." ${ }^{34}$ The postures of Dostoyevsky's characters exist in a multiplicity of shapes and forms and in many degrees of intensity.

Dostoyevsky has a dialogic relationship with his characters. Bakhtin argues that Dostoyevsky's novels are very closely related to the Socratic dialogues, where "[t]ruth is not born... inside the head of an individual person, it is born between people collectively searching for the truth, in the process of their dialogic interaction." ${ }^{35}$ Each character exists as a separate entity, as a complete consciousness. Dostoyevsky brings together disparate

THE ART OF THE Novel (New York: Harper \& Row Publishers, 1988), pp. 78-79.

33 See Mikhail Bakhtin, Problems of Dostoyevsky's Poetics, Caryl Emerson, ed. and trans., (Minneapolis: University of Minnesota Press, 5th ed. 1993), pp. 26-28.

${ }^{34} I d$., at 6 .

${ }^{35} I d$., at 110. 
ideas, "estranged and deaf to one another" and forces them "to quarrel."36 The characters in The Brothers Karamazov are never stable and static, but are constantly changing their opinions, doubting, pondering, transforming. Ideas in The Brothers Karamazov resemble molecules, bumping and colliding between characters in dialogue and within their troubled anguished minds. Characters make sudden exclamations, speak and think in fragments, have thoughts flash suddenly in their minds, make unexpected movements. Dialogue is steeped in loud exclamations, long silences, ardent confessions, endless tirades, and constant interruptions as well as composed of numerous physical gestures and expressions: blushing, growing pale, bizarre grins. The novel itself exists as a dynamic dialogue, in constant motion, unpredictable and fickle. ${ }^{37}$

Dostoyevsky's style embodies the wisdom of Montaigne, who observes that "[o]ur life is composed, like the harmony of the world, of contrary things, also of different tones, sweet and harsh, sharp and flat, soft and loud. If a musician liked only one kind, what would he have to say? He must know how to use them together and blend them. And so must we do with good and evil, which are consubstantial with our life." ${ }^{38}$ Bakhtin compares Dostoyevksy's novels to carnivals: a bunch of performers acting simultaneously according to their own rules. "Everything must be reflected in everything else, all things must illuminate one another dialogically. Therefore all things that are disunified and distant must be brought together at a single spatial and temporal 'point.' And what is necessary for this is carnival freedom and carnival's artistic conception of space and time." ${ }^{39}$ In fact, The Brothers Karamazov contains numerous scandal scenes, in which several characters are all brought together in dialogue. In the opening of the novel, Fyodor, Ivan, Alyosha, Dimitri, and Zosima, as well as others, are all thrown together in the same room. Dostoyevsky shifts much focus from postures themselves to the interaction between postures and the turbulence within postures.

\section{Ivan's and Alyosha's Postures}

The tension between abstraction and individuation manifests itself in the postures of Dostoyevsky's vast menagerie of characters. The posture of each character exists somewhere on a continuum between abstraction and individuation. Two central characters who maintain exceedingly different postures are Ivan and Alyosha Karamazov.

Ivan Karamazov maintains a posture learning heavily toward abstraction. Highly educated and deeply intellectual, Ivan was "gloomy and withdrawn" as a youth. (BK 15) Disengaged from the world, Ivan spends most of his time ensconced in abstract thought. He is proud and eagerly expounds on his views about religion and politics, which are deeply intertwined. As Albert Camus observes, Ivan places God on trial:

If evil is essential to divine creation, then creation is unacceptable. Ivan will no longer have recourse to this mysterious God, but to a higher principle--namely, justice. He launches the essential undertaking of rebellion, which is that of replacing the reign of

${ }^{36} I d$., at 91 .

${ }^{37}$ See George Steiner, Tolstoy or Dostoyevsky: An Essay in the Old Criticism (New Haven: Yale University Press, 2d edition 1996), pp. 146-147 ("Dialogues culminate in gesture; all superfluity of narrative is stripped away in order to render the conflict of personages naked and exemplary; the law of composition is one of maximum energy....").

${ }^{38}$ Montaigne, Essays and Selected Writings, Donald M. Frame, (New York: St. Martin's Press, 1963), p. 425

${ }^{39}$ BAKHTIN, supra note 33 at 177. 
grace by the reign of justice. ${ }^{40}$

"It's not God that I do not accept, you understand," Ivan says, "it is this world of God's, created by God, that I do not accept and cannot agree to accept." (BK 235) Without divine morality and order, the rule of reason leads to the notion that everything is permitted. Freed from the constraints of objective religious moral systems, the individual is free to cultivate herself to the fullest without concern for the suffering of others or for how her actions affect other individuals. Ivan spends his time pondering over various political and legal regimes to govern humankind--socialism, anarchism, totalitarianism--to replace the void created by his rejection of religious moral systems.

Self-absorbed and detached from the rest of the world, Ivan views individual instances of human suffering with disgust, for pain and pestilence mar the dignity of humankind. "Beggars, especially noble beggars, should never show themselves in the street," Ivan remarks, "they should ask for alms through the newspapers." (BK 237) Ivan despises human suffering so strongly that he cannot bear to witness it; hence, he longs for it to be hidden, tucked away in the shadowy crevices of society rather than in full open view. Ivan finds most people to be despicable; they are often stupid, selfish, squalid, and pathetic in their suffering. (BK 236-237) In one scene, Ivan encounters a drunk peasant and experiences such a powerful hatred for the peasant that when the peasant staggers into him, Ivan vigorously shoves him, sending the peasant crashing to the ground. Although Ivan realizes that the peasant, sprawled unconscious in the snow, will freeze to death in the blizzard, he strides off without further thought. ${ }^{41}$ (BK 620-621)

However, Ivan is not a cold and heartless person. He is passionate about living, and he feels great compassion for humankind. Indeed, his intellectual project has been to devise a political order that will best orchestrate human behavior and minimize human suffering. But Ivan can only feel compassion for humanity from a distance: "It's still possible to love one's neighbor abstractly, and even occasionally from a distance," Ivan declares, "but hardly ever up close." (BK 237) Fleeing to the lofty realm of abstract thought, Ivan withdraws himself from the particulars of life, from the insignificant figures who live and die in obscurity, from the instances of human misfortune that are but blips in the great expanse of eternal time. Ivan has a more universal aspiration: to help humanity as a whole transcend the wretchedness, cruelties, and petty needs of everyday existence.

Why does Ivan maintain such a distant and detached posture? Ivan's posture is formed by both an emotional and intellectual reaction to the brutalities of human behavior. Plagued by deep metaphysical and religious questions, Ivan's philosophical pursuit concerns at its foundations the quandary over judging, for he toils over how to judge the evil and suffering of life--with compassion or with condemnation.

In the chapter, "Pro and Contra," Ivan explains to Alyosha the reason for his detached posture. Ivan relates stories about a general who deliberately had a child devoured by wolves and about a little girl forced to eat excrement while locked in an outhouse throughout the frigid night. Enraged at this cruelty, Ivan craves retribution. This leads him to reject the Christian notion of redemptive divine judgment, consisting of grace, mercy, and forgiveness. Ivan rejects an afterlife where nobody is judged and condemned, where all are forgiven, and

${ }^{40}$ Albert CAmus, The Rebel, Anthony Bower, trans. (New York: Vintage Books, 1991), pp. 55-56.

${ }^{41}$ Ivan, after coming to the humbling realization that his theories have lead to the murder of his father, later rescues the peasant. See BK, at 633. 
where mothers will hug the murderers of their children.

Ivan also rejects any notion of retributive divine judgment--an afterlife in which evildoers are punished. "What do I care if the tormentors are in hell," he asks, "what can hell set right here, if these ones [children] have already been tormented?" (BK 245) Ivan wants retribution "not somewhere and sometime in infinity, but here and now, on earth, so that I see it myself." (BK 244) Ivan wants immediate judgment, and this is what leads him to rebel against divine judgment.

After he repudiates both redemptive and retributive divine judgment, Ivan attempts to find solace in human judgment (the law). "I have a Euclidean mind," Ivan declares, "an earthly mind, and therefore it is not for us to resolve things that are not of this world." (BK 235) Because God's moral order inadequately redresses the problems of human suffering, it must be replaced with a more just political and legal regime; therefore, Ivan places his faith in human judgment, which is based on reason.

Unlike divine judgment, human judgment is imperfect because it lacks full knowledge about the person judged. However, Ivan believes that human judgment strives toward redemptive divine judgment, toward a deeper understanding of the criminal. Ivan fears the recent theories of psychology will explain crime as the result of biological and demographic factors outside the criminal's control. For Ivan, the logical conclusion of these psychological explanations of criminal pathology is that nobody is to blame for criminal acts, only tragic circumstances. ${ }^{42}$ Thus, with complete understanding, the proper response to evil conduct would be compassion, mercy, and forgiveness.

Ivan rejects this conclusion, and this leads to his posture of abstraction. "I no longer want to understand anything," (BK 243) Ivan declares. "What do I care that none are to blame and that I know it--I need retribution, otherwise I will destroy myself." (BK 244) Ivan wants human judgment to remain imperfect. He avoids understanding people by distancing himself, by fleeing to a world of abstract thought. From this distant and emotionally disengaged posture, Ivan can avoid being affected by the unique details of each situation, and hence, can contain his temptations to be compassionate and forgiving.

Like Ivan, Alyosha Karamazov frames his existence in how he judges the suffering and evildoings of others. Yet in contrast to Ivan, Alyosha maintains a posture of individuated judging, loving individuals as opposed to the lofty concept of humanity. Diligently studying to become a monk, Alyosha is a "serene and even-tempered" young man, humble, caring, and loved by everyone. (BK 20) In the Prologue, Dostoyevsky notes that Alyosha "is by no means a great man." (BK 3) Alyosha's thought pales in comparison to Ivan's sophisticated intellectual theories. Yet Dostoyevsky explicitly points out that Alyosha is a "realist" and a hero. (BK 25) In order to see Alyosha in the same light as Dostoyevsky perceives him, we must focus on Alyosha's posture toward his ideas, not his ideas themselves. Although his thoughts are unoriginal, Alyosha embodies his ideas with his whole being in a way that is profound and moving.

${ }^{42}$ The implications of humankind's quest to understand the biological and demographic causes of human behavior is a familiar theme of Dostoyevsky's. In Notes From Underground, the protagonist spitefully observes: "Consequently, the laws of nature need only be discovered, and then man will no longer be answerable for his actions, and his life will become extremely easy." FYODOR Dostoyevsky, Notes From UndergRound, Richard Pevear and Larissa Volokhonsky, trans. (New York: Vintage Books, 1993), p. 24. 
Rather than remaining detached, Alyosha reacts to human suffering by moving closer to help comfort those in pain. Alyosha embraces the suffering of others, experiencing great compassion for each person he encounters, rather than ponder over abstract political and legal solutions to the problems of humankind. He is an acute observer, always aware of people's feelings and needs, and in stark contrast to Ivan's self-absorption, Alyosha becomes absorbed in the lives of others.

Alyosha does not share Ivan's urge to judge and condemn: "[H]e did not want to be a judge of men, that he would not take judgment on himself and would not condemn anyone for anything. It seemed, even, that he accepted everything without the least condemnation, though often with deep sadness." (BK 19) Attuned to the intricate particularities of each situation, Alyosha accepts the muddled confusion of the world. Alyosha loves life more than its meaning; unlike Ivan, he restrains his impulses to contort the world into a rigid order, to judge and condemn.

As this examination of Ivan and Alyosha's postures illustrates, there is no rigid dichotomy between their ideas and the rest of their personalities. Both worry about similar concerns--the suffering of humankind and the cruelty of human conduct--but both have dramatically different attitudes towards these concerns. Their different postures stem from the way they judge particular instances of individual conduct and humanity as a whole. Ivan judges abstractly; he operates at a great distance from the people he observes and evaluates. Alyosha is much closer, more ensconced in the world around him. Both his perceptions and emotional reactions diverge significantly from Ivan's.

\section{Variations on Ivan's and Alyosha's Postures}

Ivan and Alyosha's postures are impersonated by numerous other characters, in a variety of styles and degrees. The various instantiations of Ivan and Alyosha's ideas illustrate that the question of who holds them is essential, for they lead to vastly different decisions and consequences when embodied by different people with distinct temperaments and personalities.

The Grand Inquisitor, a creation of Ivan's imagination, embodies a posture of abstract judging similar to Ivan's. We encounter the Inquisitor, old and gaunt, at the time he has obtained complete obedience of the people. In the name of the Church, he has erected a new order--an earthly authority to supplant that of God--and is burning hundreds of "heretics" each day. The Inquisitor represents the culmination of Ivan's rebellion against divine moral authority. The Inquisitor has passed judgment on humankind and has begun to reconstruct a new social order, replacing God's law with positive law: "Oh, this work is still in its very beginnings, but it has begun. There is still long to wait before its completion, and the earth still has much to suffer, but we shall accomplish it and we shall be the caesars, and then we shall think about the universal happiness of mankind." (BK 257) The Inquisitor attempts to promote utilitarian happiness--an abstract measure of the success of a social order, conceiving of happiness as a formula. The Inquisitor shares Ivan's removed posture, focusing only on humankind in the abstract rather than on particular individuals. He has pursued Ivan's project of constructing a political regime to ameliorate the defects and deficiencies of human nature to its utmost consequences.

The Inquisitor acts out of selfless reasons, and he should not be dismissed as evil or 
malicious, for this ignores the paradoxical nature of his position: the Inquisitor acts out of his love for humanity. Quite distant from the consequences his rules wreak on individual lives, the Inquisitor can easily judge and condemn in the abstract, sacrificing real people for his ideal society. His law is remote from humanity; it reflects Ivan's love of the concept, rather than the content, of humankind.

Although the Inquisitor embodies a similar posture to Ivan's, it is not identical. More self-righteous and less ambivalent than Ivan, the Inquisitor has proceeded further in his rebellion. Even more detached than Ivan, the Inquisitor speaks abstractly about human nature in contrast to Ivan's catalogue of specific instances of human behavior and suffering. He has a ruthless urge to conquer, to control, to extinguish the freedom of others. Ivan has similar urges, although they are far less extreme. In contrast to the Inquisitor, who pursues his vision of a new legal regime to its bitter ends, Ivan's doubts render him unable to act.

Ippolit Kirillovich, the prosecutor of Dimitri, also embodies many of Ivan's ideas, especially Ivan's vengeful desire to condemn. Like Ivan, Ippolit esteems his Euclidean, earthly faculties, placing his faith in logic and psychology. He believes that he has a special understanding of the criminal mind. (BK 452) His closing argument in Dimitri's trial presents a passionate plea to maintain the order of Russian society, resembling the Grand Inquisitor's quest for law and order. Less concerned with Dimitri as an individual, Ippolit focuses on society as a whole; he universalizes Dimitri's case as endemic of "some general malaise that has taken root among us, and with which, as with universal evil... is already very difficult to contend." (BK 694) Unlike Ivan, Ippolit is not a sophisticated thinker; he is a narrow-minded mediocre individual. He takes up similar ideas to Ivan, but without Ivan's level of depth and nuance.

Kolya Krasotkin, a precocious schoolboy, also maintains a posture resembling Ivan's and the Inquisitor's. Mischievous without being too rebellious, Kolya is an avid reader and a good student. He has a desire to dictate and control others, and his good-spirited yet ruthless quest to mold the world to his intellectual ideas leads to the tragic death of Illyusha, a schoolboy who idolizes Kolya. After feeding a dog a piece of food with pins in it, Illyusha feels terrible guilt and remorse; Kolya hides from Illyusha the fact that the dog was not injured to teach him a lesson: "I had in mind to discipline his character," Kolya explains, "to shape him up." (BK 534) Unfortunately, Kolya does not observe the trauma Illyusha undergoes, which causes Illyusha to fall into a fatal sickness.

Kolya parrots many of Ivan's ideas. Like Ivan's repudiation of the unfathomable world of God for the Euclidean world of reason, Kolya only respects mathematics and science. (BK 551) Kolya also mimics Ivan's theories about God: "Of course God is only a hypothesis... but... I admit, he is necessary, for the sake of order... for the order of the world and so on... and if there were no God, he would have to be invented." (BK 353, ellipses in original) This resembles Ivan's rhetoric: "[T]here was in the eighteenth century and old sinner who stated that if God did not exist, he would have to be invented.... And man has, indeed, invented God." (BK 234)

Kolya is more insecure and confused than Ivan. He has not yet retreated to the realm of thought; his compassion is far less abstract than Ivan's. Although he is dogmatic and dictatorial, he does not want to teach Illyusha a lesson because of abstract reasons, but to better Illyusha the individual. Nevertheless, he is distant perceptually (Kolya is quite pensive), and he often lacks Alyosha's astute ability to observe and listen to the feelings of 
others.

Finally, Smerdyakov represents one of the most fearsome variations of Ivan's posture of judging. Smerdyakov is Ivan's "minion," taking extreme interest in Ivan's philosophical theories. (BK 623) Ellis Sandoz sees Smerdyakov as Ivan's "spiritual son"; Ivan commits deicide, and Smerdyakov parrots him by committing parricide. ${ }^{43}$ The critical difference in Ivan and Smerdyakov's postures is that Smerdyakov lacks Ivan's passion and ambivalence. Smerdyakov takes up Ivan's ideas without Ivan's inner torment, hesitation, or self-doubt. Ivan's ideas were built on a foundation of angst, a reaction to the suffering of the world. For Smerdyakov, Ivan's theories are an interesting intellectual game, and Smerdyakov is quite willing to confront their consequences. In contrast to Ivan, he can easily act out Ivan's theories.

Like Ivan's posture, Alyosha's posture of individuated judging is also embodied in various permutations. Father Zosima maintains a posture of even more individuated judging than Alyosha. Zosima is Alyosha's elder, a wise monk that serves as a mentor to Alyosha. Kind, gentle, patient, and loving, Zosima succeeds as a refutation of Ivan's grand and eloquent arguments through his posture, not through a point-by-point rebuttal. ${ }^{44}$

Zosima operates at an even closer proximity to those around him than Alyosha. Zosima is acutely perceptive, aware of others' feelings at the deepest level. Even more than Alyosha, Zosima restrains his instincts to condemn: "Remember especially that you cannot be the judge of any-one." (BK 320) Zosima, nevertheless, strives to understand rather than to judge; his judgment is so individuated that it is practically non-judgment. Zosima accepts the unfathomability of life; he has no desire to control or dominate others; his love is unconditional.

Jesus, who makes a brief appearance in the Grand Inquisitor narrative, serves as another example of a posture of individuated judgment. Like Zosima, Jesus refrains from judging. Confronted with the Grand Inquisitor's powerful indictment, Jesus remains silent, responding only with a kiss (a physical movement, not an intellectual theory). Jesus's silence and kiss are mirrored by Alyosha's virtual silence while listening to Ivan and his kiss to Ivan after hearing the Grand Inquisitor tale. Jesus is exceedingly close to the human suffering around him. Unlike the Grand Inquisitor, Jesus does not judge humankind. While the Inquisitor's compassion is cold, abstract, and tyrannical, Jesus's is liberating.

The Brothers Karamazov illustrates that it is how one takes up abstract ideas that matters, not the general principles themselves. When embodied in different personalities, similar abstract ideas and principles change and lead to vastly different consequences.

\section{The Internal Dividedness of Postures}

The motion of postures must have a locus, a source of energy. This "engine" that sets postures in motion is the internal dividedness of postures. All postures are imperfect, deeply

43 See Ellis SANDoz, Political Apocalypse: A Study of Dostoevsky's Grand InQuisitor (Baton Rouge: Louisiana State University Press, 1971), p. 111.

${ }^{44}$ Dostoyevsky indicated in a letter that he intended the anecdotes of Zosima to serve as a refutation of Ivan's theories. See Dostoyevsky's letters: No. 660 to N.A. Lyubimov, May 10, 1879 and No. 664 to N.A. Lyubimov, June 11, 1879. Cited in DAVID MAGARSHACK DostoevsKI (New York: Harcourt Brace, 1961) pp. 369-70. 
contradicted and anguished, for postures struggle with the irreconcilable tension between abstraction and individuation.

For Dostoyevsky, no posture can be pure. Although outwardly, it appears as if Alyosha maintains a stable and secure posture of individuated judgment, on the inside, he is divided and ambivalent. Alyosha often becomes confused by the events of the world, bewildered by the tangle of contradictions, conflicts, and oppositions he encounters. "One could get completely lost in this tangle, and Alyosha's heart could not bear uncertainty, for the nature of his love was always active." (BK 187) In addition to leading to confusion, Alyosha's posture creates difficulty in making conclusive judgments. (BK 157) Alyosha has an active nature to help, to become involved in each person's predicament, yet he comes so close to the situation that he often becomes ensnared in the process. Because of the depth and scope of his observation and listening, Alyosha can only act after great hesitancy, uncertainty, and angst. In order to make resolutions and to think coherently, Alyosha must partially withdraw from the chaos of particulars. Thus, Alyosha cannot maintain a posture of pure individuation. Unlike Hamlet, Alyosha does not vacillate wallow in indeterminacy; he does not ponder each side of a situation to the point of paralysis. Alyosha acts.

Thus, Dostoyevsky deeply complicates Alyosha, for beneath his graceful and merciful exterior, Alyosha possesses many of the same base instincts as his brothers. What makes Alyosha compelling as a character is his very dividedness and ambivalence, the fact that his posture gravitates in dangerous directions. After Zosima's body begins to stink after he dies, leading many monks to wonder whether he had been a clandestine evildoer, Alyosha becomes enraged at this injustice and struggles with his faith. He triumphs, yet we witness his Dimitri-like passionate nature and his Ivan-like rebelliousness, which is usually hidden and subdued. Unlike pure ideas, postures are unstable and uncertain, and Alyosha's posture is in constant danger of shifting toward Ivan's.

Just as Alyosha is divided, Ivan is deeply divided as well. Ivan is not purely intellectual; he is also quite passionate, and his theories are crafted out of anguish. "Sticky spring leaves, the blue sky--I love them, that's all! Such things you love not with your mind, not with logic, but with your insides, your guts." (BK 230) Ivan is not merely a nihilist; he is seeking a positive solution to his rebellion. ${ }^{45}$ The Inquisitor legend is an attempt to solve his deep concerns. Earlier in the novel, after Ivan declares his rebellious views, Zosima replies: "The idea is not yet resolved in your heart and torments it." (BK 70) Zosima refers to Ivan's unresolved "heart," to his emotional reaction toward his position. Later, Ivan says to Alyosha while making his arguments: "[I]t's not that I want to corrupt you and push you off your foundation; perhaps I want to be healed by you." (BK 236) Ivan is constantly seeking a response to his ideas; perhaps he secretly desires to be refuted.

Ivan's theories seem contradictory at their core. Ivan repudiates God's order. But in a world without God "everything is permitted." This, however, would result in a Hobbesian state of nature in which might makes right; the strongest and most powerful would rule; anarchy, murder, and violence would reign. Yet Ivan rebelled against God because he could not tolerate the evil and violence of the world. This is the paradox at the heart of Ivan's posture. Ivan can only present an unsatisfying fictional solution to this paradox: the Grand Inquisitor. Ironically, Ivan, a radical individualist, can only imagine a solution of complete authoritarianism. Ivan's fictional solution, a posture of radically abstract judgment, was aimed at helping humanity but leads to terror and death rather than social harmony.

${ }^{45}$ See SANDOZ, supra note 43 at 183. 
Ivan actually realizes the problems in his own posture and in the posture of the Grand Inquisitor. He refers to the Inquisitor parable as an "absurd thing," (BK 246) as a "muddled poem by a muddled student." (BK 262) Ivan is ambivalent and unresolved about the very core of his beliefs. The ability to judge and condemn humankind is essential to both Ivan and the Inquisitor's postures, yet Ivan views it with skepticism: "[C]an it be," Ivan wonders, "that any man has the right to decide about the rest of mankind, who is worthy and who is more unworthy?" (BK 143) Moreover, when Ivan observes another person sharing a similar posture, he reacts with great revulsion. Returning home after espousing his views to Alyosha, Ivan envisions Smerdyakov, who incarnates many of Ivan's own ideas, sitting in his soul, and he feels an intense loathing for Smerdyakov.

Even the Inquisitor is ambivalent. When Jesus gently kisses the Inquisitor, "[t]he old man shudders... The kiss burns in his heart, but the old man holds to his former idea." (BK 262) Although the kiss fails to change the Inquisitor's convictions, it leaves him deeply troubled.

\section{The Interrelatedness of the Postures}

Postures of judgment exist in dialogue with each other, and can constrain and clash with each other. However, all postures of judgment are closely related, even the most radically opposite. All of the characters are quite similar; they all toil with the same ideas. In fact, they seem to be multiple variations of a singular character. The novelist Milan Kundera once wrote that "The characters in my novels are my own unrealized possibilities. That is why I am equally fond of them all and equally horrified by them." 46 Literature is an exploration of the possibilities of the self, realms of existence which might be too dangerous, too frightening, too impossible to discover.

Both Ivan and Alyosha's postures have similar roots. Like Ivan, Alyosha shares in the Karamazov force; he has the same turbulent passion as his brothers. Rakitin says to Alyosha, "You are a Karamazov yourself, a full- fledged Karamazov.... You're a sensualist after your father." (BK 80) When Dimitri confesses his depravity to Alyosha, Alyosha blushes. "I blushed not at your words, not at your deeds, but because I'm the same as you." (BK 109) Alyosha's and Ivan's passion leads both brothers to care deeply about the suffering of humankind. Alyosha agrees with Ivan's starting point--the meaningless suffering of innocent children. Ivan dares Alyosha to refute the bedrock of his rebellion:

Tell me straight out, I call on you--answer me: imagine that you yourself are building the edifice of human destiny with the object of making people happy in the finale, of giving them peace and rest at last, but for that you must inevitably and unavoidably torture just one tiny creature, that same child who was beating her chest with her little fist, and raise your edifice on the foundation of her unrequited tears--would you agree to be the architect on such conditions? ${ }^{47}$ (BK 245)

Alyosha, like Ivan, refuses to create such a society.

\footnotetext{
${ }^{46}$ Milan Kundera, The Unbearable Lightness of Being (New York: Harper \& Row Publishers, Inc., 1984), p. 221.

${ }^{47}$ For an interesting story based upon Ivan's hypothetical, see URSULA K. LE GUIN, "The Ones Who Walk Away from Omelas," in THE WIND's Twelve QuARTERS (New York: Harper \& Row, 1975), p. 275
} 
Thus, Ivan's rebellion is born out of a posture of individuation, a subordination of the abstract societal order to the particular injustice of one specific instance. The empathy that leads to Alyosha's posture of individuated judging can easily lead to a posture of extreme abstraction. The totalitarian regime of the Inquisitor originates from love--a similar love to Jesus' and Alyosha's--from compassion for individual suffering. Richard Weisberg accurately observes that "Ivan's story graphically illustrates how quickly the notion of love, elevated to a communal precept, turns into chilly formalism and mass hatred." ${ }^{48}$ The Inquisitor's compassionate understanding of the weakness of human nature spawns his ability to gain submission and obedience. "What about the role empathy may play in producing morally horrible results?" Lynne Henderson asks, "To the extent Hitler understood the experience, pain, and desires of Germans, it may be that he was able to manipulate them." 49

In an ironic illustration of the closeness of the postures, the Inquisitor is dressed in an "old, coarse monastic cassock," (BK 249) the same way Alyosha dresses. The interrelatedness of Alyosha's posture with that of Ivan and the Inquisitor illustrates that no matter how opposite or radical, postures are quite similar. A few subtle movements can generate postures as distinct and contradictory as Ivan's and Alyosha's.

In fact, Ivan and Alyosha's positions cannot exist apart from each other. Alyosha's posture is a position toward others--he suffers vicariously, listens, and reacts. Ivan's posture is a reaction against Alyosha's position, and Ivan wants his position to be challenged and resisted. Thus, Dostoyevsky illustrates that postures cannot exist independent of each other, and that we should focus not only on individual postures, but on the relationships between them.

\section{A Jurisprudence of Postures}

The question of fit is decided in the physical and temporal dimensions of judging. Each character's unique contortions of the ideas lead to vastly different consequences in their judgments and conduct. As illustrated by the various permutations of postures in The Brothers Karamazov, the application of general propositions depends upon how they are embodied. Like all of us, judges have bodies. They must perceive what they judge; they must establish a distance they are comfortable with; they must find an appropriate level of psychological engagement.

\section{The Physicality of Postures}

Judging occurs from a spatial position in relationship to life. We understand the world in a physical way, in terms of location, presence, and motion. This is why we speak of a person's position on an issue. Richard Brookhiser, writing about George Washington, observed the importance of the physical body:

The body is the basic unit of all human intercourse, including politics. Civilization modifies or suppresses that fact, in the interest of cultivating other aspects of people. Yet even rulers who are intelligent, prudent, or visionary must make a sensual impact if they are to lead. If their bodies cannot command attention, they must compel it by secondary

\footnotetext{
${ }^{48}$ WeISBERG, supra note 4 at 67.

${ }^{49}$ Lynne Henderson, "Legality and Empathy," 85 Michigan Law Review 1574, 1585 (1987).
} 
means, such as eloquence, or by props.... ${ }^{50}$

The body is an essential dimension of ideas, discourse, and persuasion, and separating the activity of judging from the body within which it occurs will alter its nature. Every judgment has, as its source, a body and a location. Viewing judging as an activity performed from a posture emphasizes a judge's physical presence--her location within multiple contextual planes with forces pulling in all directions. Judging involves a set of relationships: between the judge and the judged, the judgments of others, and the judge herself.

We judge at a certain distance from the object of our particular judgment. Ivan and Alyosha's postures differ most drastically in the distance they maintain between themselves and the instances of human suffering they encounter. Distance is both perceptual and psychological. Perceptual distance involves the amount of information informing the judgment. As we increase our distance from a situation, we perceive less data and detail. We perceive life as photographers, with a bounded perspective on life. When adjusting the focus on a camera, the photographer often cannot simultaneously focus on both the subject in the foreground and the scenery in the background.

Psychological distance involves the amount of emotional involvement between the judge and the judged. Take, for example, Ortega y Gasset's analogy to a scene in which a man is dying. ${ }^{51}$ Four people attend his bedside: his wife, a doctor, a newspaper reporter, and a painter. Each of these witnesses observes the death from a different point of view, for each stands at a distinctive psychological distance from the dying man. The wife is the least distant, experiencing the death of her husband personally and emotionally. The doctor is more distant, for tending to the dying man is merely a professional responsibility. For the reporter, the death is just a spectacle. The painter is the most distant of all, concentrating only on the appearance of the death. Since he is so emotionally detached, he can find beauty even in the most morose of events. Ortega observes that the great disparity of psychological distance between the wife and painter leads each to witness the events of the death as if it were an entirely different event. Similarly, in The Brothers Karamazov, the effects of love and compassion for humanity differ drastically depending upon the degree of psychological distance each character maintains.

Thus, the level of generality with which a judge perceives the facts of a case has a profound impact on how she interprets these facts. Interpreting the facts involves sifting out the trivial ones and locating the nuggets--those facts which are critical to the decision that must be made. This interpretation is vital to how judges categorize cases, in how judges determine whether a case fits under an general proposition.

We perceive events and situations at varying levels of generality. At a high level of generality, we do not notice subtle differences, but at a more individuated level, we can observe the unique intricacies of each case. For example, we will not notice the differences between two snowflakes unless we examine them closely.

As proximity increases, a judge will often become more aware of the imprecision of general legal propositions. For example, in Lorenzo v. Wirth, ${ }^{52}$ Judge Holmes, then a state court

\footnotetext{
${ }^{50}$ Richard Brookhiser, "A Man on Horseback," Atlantic Monthly (Jan. 1996) 50, at 55.

${ }^{51}$ See Ortega y Gasset, "The Dehumanization of Art," in A MODERN BooK OF EstheTics, Melvin Rader, ed. (New York: Henry Holt \& Co., 1952), pp. 433- 435.

5249 N.E. 1010 (Mass. 1897).
} 
judge, held that a defendant should not be liable when a plaintiff fell into an open coal hole on the defendant's property. Holmes declared: "A heap of coal on a sidewalk in Boston is an indication according to common experience that there very possibly may be a coal hole to receive it." After reading Holmes' opinion, this appears to be a rather easy case. However, Judge Knowlton, dissenting, supplies a critical fact that Holmes left out: the plaintiff had just come from Spain and had never seen coal put into a cellar through a coal hole. The introduction of more facts makes the case more unique, and thus more difficult to fit into general categories. Indeed almost any case, when viewed at a great distance, when depicted in the most general of terms, will present no difficulties for general legal propositions. As Judge Richard Posner wrote: "The more facts that are stated in an opinion, the easier it is for judges in subsequent cases to distinguish, narrow, confine, and otherwise diminish the scope and impact of the opinion. ${ }^{n 3}$

Perceptual and psychological distance are closely related. Often, increased perceptual proximity--learning more facts--yields an increase in psychological proximity--deepened concern and understanding, and less tolerance of the imprecision of general propositions. Most often, the emotions aroused by proximity are compassion and love. Of course, proximity can also lead to loathing, but when we despise something, we tend to recoil and distance ourselves; thus, we are often closer to what we like.

Proximity can complicate judging. Individuated judgments often lose sight of larger societal goals. What is good in each instance might not be good in the aggregate. Such is the case in the tragedy of the commons, in which rational individual choices will lead to the over-exploitation and ruin of common lands, ${ }^{54}$ and prisoner's dilemma, in which decisions made individually and independently will fail to produce the best outcome.

By overindulging in the unique particularities of each situation, judgment will become confounded in a chaos of facts, the issue will become too complex to handle, and a resolution will become impossible to reach. ${ }^{55}$ Understanding and compassion makes the task of judging more difficult and ambiguous. In Karel Capek's "The Last Judgment," a recently-deceased criminal finds himself before a divine tribunal to determine his fate. In an interesting twist, the judges are human and God is the witness. God testifies about the defendant's crimes but reveals the tormented childhood that caused the defendant's behavior. God relates the inner goodness of the defendant, how circumstance and bad luck turned him into a criminal. But the judges still condemn the defendant to hell. Surprised and dismayed, the defendant asks God why He is not the judge. God answers:

Because I know everything. If judges knew everything, absolutely everything, they couldn't judge, either: they would understand everything and their hearts would ache. How could I possibly judge you? Judges know only about your crimes but I know everything about you. Everything Kugler. And that's why I cannot judge you.... Believe me, Kugler,

\footnotetext{
${ }^{53}$ Richard A. Posner, Cardozo: A Study in RePutation (Chicago: University of Chicago Press, 1990), p. 42.

${ }^{54}$ See Garrett Hardin, "The Tragedy of the Commons," 162 Science 1243 (1968).

${ }^{55}$ Mark Yudof argues that too much of the human voice, which focuses on individual circumstances in judgment, will thwart the aims of formal justice and resulting in decisional paralysis. See Mark Yudof, "'Tea at the Palaz of Hoon': The Human Voice in Legal Rules," 66 Texas Law Review 589, 605-06 (1988). Mark Tushnet also notes that "attention to particulars may lead to emotional flooding." Mark Tushnet, "The Degradation of Constitutional Discourse," 81 Georgia Law Journal 251, 254 (1992). In contrast, Lynne Henderson argues that it is a myth that "empathy leads to moral or decisional paralysis." Henderson, supra note 49 at 1584.
} 
this is the way it should be. The only justice people deserve is human justice. ${ }^{56}$

Proximity--a close perceptual and psychological distance--often leads to mercy. Mark Yudof aptly notes that there is a "curious relationship between forgiveness and proximity." ${ }^{57}$ When we learn to see the world from someone else's shoes, our judgment changes significantly, often in a more compassionate and caring direction. Proximity complicates our desire to condemn. Thus, for Ivan and the Inquisitor, who are detached, distant, and ensconced in abstract thought, condemnation is easy; for Alyosha and Zosima, who are very close to particular individuals, judgment is extremely difficult.

"We spend millions of dollars to save the lives of clearly identified individuals who are in immediate danger--dollars, which, if applied to generalized safety, would protect and preserve many more." Judge Guido Calabresi observes. ${ }^{58}$ In essence, Judge Calabresi notes that we often value real lives more than statistical lives. We feel closer to real individuals, not lives in the abstract. Even in law and economic approaches, we must ascribe values to certain things, such as human life. Calabresi's observation points to the importance of distance; the value of a life to a jury, which is often presented with the unique details of a person's existence, is often vastly greater than the value of a life in the abstract.

Variations in distance not only affect how decisionmakers decide cases but how cases affect decisionmakers. We are often more influenced by the concrete examples we experience as opposed to abstractions and rules. ${ }^{59}$ The process of judgment is a two-way street, changing the world that is judged as well as the individual who judges.

The location of postures is influenced by momentum. As proximity influences the decisionmaker to use more individualized judgment, distance has the opposite effect. Abstract rules can cover up their injustices. A clear rule will often not be litigated. Only when it seems as though a rule will be overturned or changed will litigation arise. So in many instances, the injustices of the abstract rule are hidden, for they are never brought before a court of review. Increasing proximity in a few cases can lead to even more proximity in subsequent cases. By increasing the flexibility of law, courts invite more cases, and thus get closer to the problems. Cases that would not ordinarily come to court now come in droves.

Distance is also a product of the constraints of a judge's context. Each posture judges in a multiplicity of contexts. Even when judging occurs through a case-by-case method, it occurs not just within the context of any one particular case, but in a larger context consisting of a series or group of cases. Judgments must blend into the fabric of the law, which is woven together by multiple judgments made by different actors. Context is internal as well as external: judges strive for consistency in judging not only within a certain body of law, but within their own individual style of judging. Contexts often change; a person can exist in multiple contexts simultaneously; and contexts often pull in different directions. A judge must be faithful to the law, to her personal judicial style, and to each individual case.

${ }^{56}$ Karel CAPEK, "The Last Judgment," in Tales From Two Pockets, Norma Comrada, trans. (1929; New Haven: Catbird Press, 1994), pp. 159-160.

${ }^{57}$ Yudof, supra note 55 at 603.

${ }^{58}$ Guido Calabresi, Ideals, Beliefs, Attitudes and the LaW (Syracuse: Syracuse University Press,, 1985), p. 6.

59 See Richard Nisbett and Lee Ross, Human Inference: Strategies and Shortcomings of Social Judgment (Englewood Cliffs: Prentice Hall, 1980). 
Maintaining these various fidelities is a difficult balance.

Thus, the decision about where we embody certain judgments is critical to the substance of those judgments. Each legal actor--the legislator, executive, judge, attorney, juror, client, professor, and public--has a distinct relationship to the particular case at issue, special constraints and freedoms, unique experiences typical of her position and a certain range of permissible distances from which to judge. Judges are required to explain their decisions; juries are not. Legislatures, despite having vast resources of data and evidence when creating laws, cannot possibly consider all possible cases; judges are often constrained by the facts and issues of the cases before them. Judges must make judgments in a series of cases; juries disband immediately after their decisions.

Who shall make certain judgments influences where they shall be made, their location and distance. Juries are particularly close to the situation to be judged; they exist solely to make a judgment in that particular case. Judges are further away, and their distance depends upon what type of judge they are. Appellate judges only get a filtered-down version of the facts. Karl Llewellyn analogized the process of deciding a case to a fact-sifting process. An appellate decision is vastly removed from an individual event, for the facts considered go through numerous stages of attrition; only those relevant for appeal and essential for the appellate decision remain. ${ }^{60}$ "Appellate decisions," writes Judge Calabresi, "often transform the question to be decided from one involving human actors whose behavior has created the necessity to decide to an abstract proposition."

\section{The Temporality of Postures}

Postures are not only physical, but temporal, locations. Judging is a continuous process that changes the individual and her style of judging as it occurs. Judging should not be discussed as a static concept but as a process constantly in motion. Examining the temporal dimension of judging focusses on several concerns: When is the judgment made in relation to the judge's life? How long does the judge have to deliberate? When, historically, is the judging taking place? In what order are judgments being made?

Legal judgment is characterized by the fact that decisions cannot be postponed indefinitely. The time pressures in which judges must decide can substantially affect the judgment. In New York Times Co. v. United States, several Supreme Court justices complained about the severe time pressure they faced in deciding the case. "We all crave speedier judicial processes," Justice Burger wrote in dissent, "but when judges are pressured as in these cases the result is a parody of the judicial function." ${ }^{62}$ Time constraints can serve to distance judges by preventing them from gathering facts and details but can also increase proximity by sharply focusing a judge on a particular situation without permitting a judge the ability to engage in extensive thinking about more abstract jurisprudential issues.

Individuated judgment is very time-consuming; facts need to be discovered, presented, and considered. Our legal system simply does not have enough time and resources to make all judgments as individuated as possible. This fundamental limitation of legal judgment is manifest in the problem of the slippery slope. Law "calls upon today's decisionmakers to

${ }^{60}$ See Llewellyn, BRAmBle Bush, supra note 10 at 35.

${ }^{61}$ Guido Calabresi and Philip Bobbitt, Tragic Choices (New York: W.W. Norton \& Co., 1978), p. 210.

${ }^{62} 403$ U.S. 713 (1971). 
consider the behavior of others who tomorrow will have to apply or interpret today's decisions." ${ }^{63}$ Judges do not just focus on the instant case, but ponder how future judges will decide based on their decision. The slippery slope fear concerns the risk, created by the decision, that future decisions will slip down the slope. ${ }^{64}$ Thus, legal decisions are made in constant awareness of the problem of time.

In our common law system of precedent, the order in which cases come before judges is critical in forming the law. The first case on an issue forms the original precedent, which will then be applied to all subsequent cases. The shape of law (and our lives) is formed through the unfolding of experience. Our conceptions of ourselves, which influence our present judgments, are formed from the particular chronology of our past; the law is no different. Too often judges and legal scholars view law as a snapshot. But the wondrous aspect of law is its dynamism and fluidity. Law is not just a collection of rules and cases that dictate precise results, but a protean entity, interacting with the historical and cultural setting in which it exists. "The rules change as the rules are applied," observed Edward H. Levi. ${ }^{65}$ Law is a set of evolving standards--not always a progression--yet we cling to the idea of stability. Each posture is pulled, pushed, and jostled in all directions by the experiences of life. Every posture can succumb to positions of extreme abstraction or individuation; our postures are not static.

Like the postures of Dostoyevsky's characters, legal postures are internally divided. Although judges often strive for consistency in judgment, rarely are they entirely stable. Judges often change their attitudes over time. "We grope and feel our way," Justice Cardozo wrote, "What we hand down in our judgments is an hypothesis." ${ }^{66}$ Rarely do judges judge consistently according to their stated jurisprudential philosophies. This does not represent the judges' failings as much as it does the inability of simple labels and static descriptions, to adequately capture a posture of judgment. Dworkin's deductive account of judging masks the dynamism of postures. Legal judgments consist of much more than their final forms, which are often veiled beneath a guise of conviction and solidarity. Frederick Schauer notes that although numerous factors inform a judge's decision to apply statutes to particular cases, if the judge decides that the statute should prevail, "mere citation of the statute as inexorably dictating the result would conceal... from society the actual determinative factors." ${ }^{67}$ Postures are in a state of constant negotiation over the proper perceptual and psychological distance from what is judged.

In our postmodern world, our law is the product of multifarious perspectives and peoples, with vastly different and often conflicting interests. Law is created over numerous historical periods, by different groups in power, by different individuals with different goals, and is applied in numerous communities. Because much of the law is composed by the procession of particular cases through the system, law is fragmented and uneven. "[W]hat passes before judges on the reviewing stand," wrote Judge Traynor, "is not a well-programmed, orderly parade, but fragments from a circus on the loose." ${ }^{68}$ While Dworkin's analogy of judging to writing a chain novel is instructive, it is also imprecise in a fundamental way. Unlike a

${ }^{63}$ Frederick Schauer, "Slippery Slopes," 99 Harvard Law Review 361, 383 (1985).

${ }^{64}$ See id., at 376.

${ }^{65}$ Edward H. Levi, An Introduction to Legal Reasoning (Chicago: University of Chicago Press, 1949), pp. 3-4.

${ }^{66}$ BENJAMIN CARDOZO, LAW AND LITERATURE AND OTHER ESSAYS in ESSAYS, supra note 11.

${ }^{67}$ Frederick Schauer, "Formalism," 97 Yale Law Journal 509, 517 (1988).

${ }^{68}$ Roger J. Traynor, "The Limits of Judicial Creativity," 29 Hastings Law Journal 1025, 1026 (1978). 
novel, law is not a progression toward a single denouement. Novels develop toward a conclusion; each chapter has a direction; each chapter is a crucial link in a progression toward a conclusion. Perhaps law is better described as a layered collage, pasted together in an often disorganized ad hoc manner, unfolding before us in ways we do not entirely understand and cannot completely foresee. 


\section{Navigating the Nomos of Postures}

"We inhabit a nomos--a normative universe," wrote Robert Cover. "We constantly create and maintain a world of right and wrong, of lawful and unlawful, of valid and void." The world of postures is a nomos, and judging is inescapably a normative practice.

How ought one to judge? Can postures be evaluated? How can judges improve their postures? In the rest of this essay, I will address these questions. I will explain that although there is not a set of general propositions that can instruct judges how best to navigate the tension between abstraction and individuation, judging can be improved through wisdom and practice. Literature, rather than supplying a systematic network of abstract normative proscriptions, is a fertile source of specific and concrete wisdom about how to judge. Literature provides substantial insight into postures because, like law, literature struggles to establish a workable position between abstraction and individuation.

\section{A. Legal and Literary Postures}

Both law and literature are disciplines which necessitate, influence, and constrain various postures of judging; each discipline establishes a range of possible postures. While The Brothers Karamazov illustrates several postures of legal judgment, the novel discusses as well as serves as evidence of literary judgment. Because any posture of legal or literary judgment must deal with the tension between abstraction and individuation, these two categories of judgment share similar difficulties and constraints. Moreover, both law and literature are fields where abstract ideas are applied to difficult factual contexts, where these ideas are challenged because they must exist in the arena of reality. Do law and literature differ in the postures of judging that they permit? Are these differences important? What insights can we discover by analyzing the overlap in the postures that both disciplines will permit? Analysis of these questions in light of The Brothers Karamazov will cast doubt on the way we traditionally distinguish between legal and literary judgment, and illustrate that law and literature are so interrelated that they are composed of each other.

The way judging takes place has substantive effects on the content of the judgment. In this section, I will compare and contrast legal and literary postures of judging to expose the constraints unique to legal judging and how they affect the outcome of these judgments. But the more important goal of this section is to show the similar struggle between abstraction and individuation that both legal and literary judging share and illustrate the different ways that works of literature creatively navigate this tension.

\section{Legal Judgment}

Through a series of brilliant juxtapositions, Dostoyevsky illustrates the contrasts between law and literature. In the first half of the novel, Dostoyevsky juxtaposes two narratives: the legend of the Inquisitor and the autobiography of Zosima; he places Ivan's posture in dialogue with Alyosha's. The second half presents the crime, arrest, investigation, and trial. The first half is a trial of divine judgment and the second half is a trial of human judgment, a meta-trial in which the trial itself is on trial. The first half concerns the creation of law and of legal systems and the second half concerns the application and interpretation of law.

The investigation of Dimitri marks the law's formal entrance into the novel, which 
culminates in the trial. ${ }^{69}$ The investigation and trial represent legal judgment as a whole, as distinct from each character's particular posture of judgment. The trial is an arena which permits and constrains various types of judgments, and it serves as an excellent example of the nature of legal judgment--its range, variety, strengths, and weaknesses. In Dimitri's trial, the defense attorney (Fetyukovich) and the prosecutor (Ippolit) attempt to retell the events that occurred in the earlier parts of the novel. In typical Dostoyevskian fashion, the trial, which itself is a division of competing narratives, is juxtaposed against the rest of the novel. In this manner, Dostoyevsky exposes the contrasts between the legal judgments of the trial and the literary judgments of the novel.

The investigation and trial impose an artificial legal framework around previously-narrated events. "The entire thrust of the legal procedure," observes Richard Weisberg, "is to recreate verbally, and thus to devalue, the existence of the spontaneous, vital individual who stands accused." ${ }^{70}$ The process of law appears to be a process of creation rather than explication. This is especially explicit in the courtroom, in which we witness the earlier happenings through the lens of the law, through which everything seems bizarre and unnatural. Dimitri is dressed like a "terrible dandy," not appearing as he normally does. (BK 660) Ivan, usually rational and intellectual, appears as a rambling lunatic. Four witnesses are not present--including the most important witness: the actual murderer, Smerdyakov. Two key participants of the trial--a Moscow doctor and Fetyukovich, a St. Petersburg defense attorney--are outsiders from the small town where the events occurred. Fetyukovich, Dimitri's attorney, "remained an enigma to everyone." (BK 663) As Weisberg observes, "the legal figures in The Brothers Karamazov (including Fetyukovich, the defense attorney), immediately convinced of Dimitri's guilt, seek only to emphasize those aspects of the suspect's personality which appear to indicate his culpability, and then to narrate a version of the Karamazov reality in accordance with their preconceptions." ${ }^{71}$

The trial's failure to reveal the truth of the crime stems from its great distance from the facts and the abstraction of its judgment. The prosecutor, for example, maintains a posture of abstract judgment similar to Ivan's. Weisberg notes: "[Ivan and Ippolit] consciously attempt to model reality into preconceived form. Both fail to arrive at an ultimate vision of truth because truth refuses to submit to that form." ${ }^{17}$ Although Ippolit has "a special gift of comprehending the criminal and his crime," (BK 452) he, like Ivan, refuses to believe that no one is to blame. Rather, he prosecutes and condemns, for he has the same instinct for revenge as Ivan. (BK 693) Ippolit looks to the whole, urging Dimitri's conviction to preserve order in Russian society. (BK 693-694) Yet, the trial tragically demonstrates that Ippolit's psychological theories fail to account for what really happened. The tragedy is compounded by the fact that Dimitri's own attorney also fails to understand Dimitri. "He Fetyukovich just doesn't believe a pennyworth of what I say," Dimitri tells Alyosha, "He thinks I killed him." (BK 593) Nobody--not the prosecutor, not the defense attorney, not the jury--understands the nature of Dimitri or the true origin of the crime. When Dimitri attempts to explain himself, exclaiming that he is guilty of being a scoundrel but not guilty of his father's death, the judge admonishes him to avoid "irrelevant" exclamations." (BK 661-662) Bakhtin observes: "All who judge Dmitry are devoid of a genuinely dialogic

${ }^{69}$ Despite many similarities to modern American adversarial procedure, the procedure used for Dimitri's investigation and trial was Continental procedure. For a discussion of Dostoyevsky's use of legal procedure, see WEISBERG, supra note 4 at 44-48.

${ }^{70} \mathrm{Id}$., at 59.

${ }^{71}$ WEISBERG, supra note 4 at 55.

${ }^{72} I d$., at 79 . 
approach to him, a dialogic penetration into the unfinalized core of his personality." ${ }^{73}$ Dostoyevsky's depiction of the investigation and trial of Dimitri reveals that legal factfinding processes are deeply substantive in origin and effect. The law's misunderstanding of Dimitri and the events of the parricide stems from the Ivanesque postures of the legal actors in The Brothers Karamazov.

Legal judgment, by its very nature, fosters a range of postures that tends toward a substantial degree of abstraction. Legal systems deliberately constrain the information available to the decisionmaker. Numerous evidentiary rules, such as the exclusionary rule, are often the product of goals and policies other than the quest for a complete understanding of the events in dispute. As Justice Frankfurter observed, "A trial is not a 'free trade in ideas,' nor is the best test of truth in a courtroom 'the power of thought to get itself accepted in the competition of the market.' [A] court is a forum with strictly defined limits for discussion. It is circumscribed in the range of its inquiry and in its methods by the Constitution, by laws, and by age-old traditions...." ${ }^{74}$ Since legal judgment must end in a final judgment, a certain degree of abstraction must enter into the process. In order to achieve closure, to resolve a case with finality, legal judgment must limit the amount of factual information that is taken into account. Constraints on the amount of available facts and information lead to a distancing from the accused. Thus, law must exist at a distance from our lives; its ability to judge, condemn, and punish arises because it does not strive for pure understanding.

\section{Literary Judgment}

In law, as opposed to literature, judgment often results in physical force. "Legal interpretation takes place in a field of pain and death," writes Robert Cover, "...Legal interpretive acts signal and occasion the imposition of violence upon others: A judge articulates her understanding of a text, and as a result, somebody loses his freedom, his property, his children, even his life. ${ }^{175}$ Legal judgment results in action. Kuznetsov observes: "For Hamlet's tragedy consisted in his realisation of the complexity of existence. To act one must at some point put an end to the complicating of thought.... Infinitely complicated thought cannot result in action." ${ }^{76}$ Legal judgment does not have the range of freedom which literary judgment possesses.

In contrast to law, literature does not revolve around a final judgment. The facts literature admits into its narrative are not limited by the necessity of a final judgment, for literature can end unresolved. The novel redeems Dimitri, supplying all the subtle details missing from the trial (most importantly, Dimitri's spiritual crisis and Ivan's philosophical beliefs which engender the crime). Only literature can explain Dimitri's change of heart, his sudden decision not to kill his father. Literature frequently redeems the criminal. Without the rest of the story to explain the details, Melville's Billy Budd would appear to be just another murderer. The newspaper article at the end of the story would be all that remains of the incident. But Melville supplies the necessary details, leading the reader to desire to exonerate Billy. Literature allows us to feel compassion for the monstrous Frankenstein in Mary Shelley's Frankenstein, as well as to feel empathy for Achilles' enemy, Hector, in Homer's The Iliad. Paul Gewirtz aptly observes: "Literature makes its special claims upon us

\footnotetext{
${ }^{73}$ BAKHTIN, supra note 33 at 62.

${ }^{74}$ Bridges v. State of California, 314 U.S. 252, 282 (1941) (Frankfurter, J. dissenting).

${ }^{75}$ Robert Cover, "Violence and the Word," 95 Yale Law Journal 1601, 1601 (1986).

76 Boris KuZNETSOV, EINSTEIN AND DostoyevsKY, Vladimir Talmy, trans., (London: Hutchinson Educational Limited, 1972), p. 64.
} 
precisely because it nourishes the kinds of human understanding not achievable through reason alone but involving intuition and feeling as well." ${ }^{77}$ Like Alyosha, literature is constantly striving toward grace and does not demand judgment. It questions and stifles judgment, creates doubt and uncertainty. Thus, literature permits a range of postures that is able to lean more toward individuation than law. Martha Nussbaum argues that the ideas of literature "cannot be fully and adequately stated in the language of conventional philosophical prose... but only in a language and in forms themselves more complex, more allusive, more attentive to particulars." ${ }^{78}$ Legal judgment will never achieve the freedom of literary judgment, for law is doomed to a certain uncompromising degree of abstraction.

Yet even this distinction between law and literature is highly mitigated. Although literary judgment seems to be more capable of individuation than legal judgment, it is internally divided like a Dostoyevskian character, struggling with a tension between abstraction and individuation. The creation of a literary narrative involves judgment. The author must determine which details shall compose the narrative, the scope and emphasis of the topic. Some narratives create an illusion beguiling us into believing that it is reality. Others comment about reality rather than portray reality directly. Some narratives do not attempt to portray how reality is but how reality appears or how reality feels. Nevertheless, a literary narrative is an abstraction from the subject of its presentation. Albert Camus, in The Rebel, views the creation of art as similar to Ivan's metaphysical rebellion against God: "Artistic creation is a demand for unity and a rejection of the world." ${ }^{17}$ The creator of a narrative strives for coherence and order in a world of chaos; it is this very imperfection of art's representation that constitutes its style, distinguishing it from the world it represents, evoking meaning by imposing a certain pattern on the world. In his 1925 essay, The Dehumanization of Art, Ortega y Gasset discusses the tension between art and representation. Ortega makes the analogy between a work of art and a window looking out onto a garden: "to see the garden and to see the glass in the windowpane are two incompatible operations." ${ }^{80}$ The reader can either focus on the style of the narrative itself (the window) or the reality represented (the garden). All narratives are stylizations to some degree, and thus, by their very nature, they exist at a distance from the objects they represent. Thus, some of the abstraction of legal judgment is an essential aspect of literary judgment. "The virtue of art lies in detachment," wrote Emerson, "in sequestering one object from the embarrassing variety." ${ }^{11}$

The Brothers Karamazov is obsessed with narratives, and a substantial portion of the novel is devoted to revealing the imperfections of narratives, the fact that they are abstractions. Dostoyevsky's narrator draws attention to his literary judgments, forcing the reader to recognize that the novel is not reality, but a narrative, consciously constructed by an author with an agenda. For example, the narrator, lacking specific information concerning the death of one of Fyodor's wives, presents two contradictory accounts. (BK 9) The narrator relates the homilies of Zosima from Alyosha's notes, which are of dubious accuracy. As Dostoyevsky seems to be pointing out, all narratives are a distortion of reality. Just as the law's retellings of the crime in the trial fail to express the full truth, the literary narrative is also an abstraction with similar problems. In fact, the many silences in the novel, especially

\footnotetext{
${ }^{77}$ Paul Gewirtz, "Aeschylus' Law," 101 Harvard Law Review 1043, 1050 (1988).

${ }^{78}$ NuSSBAUM, supra note 29 at 3.

${ }^{79}$ CAMUS, supra note 40 at 253.

${ }^{80}$ Ortega y Gasset, supra note 51 at 431.

${ }^{81}$ RalPh Waldo Emerson, "Art," in EsSays: FirSt AND SeCONd Series (New York: Vintage ed. 1990), p. 202.
} 
Christ's silence when listening to the Inquisitor, show the limits of narrative, the inability of any form of abstraction to explain or express reality adequately. ${ }^{82}$

The novel's simultaneous attack yet reliance on its narrative existence illustrates literature's paradoxical nature, its inner dividedness. Literature has a similar abstract nature as law, yet it can also question its own being. ${ }^{83}$ it can muddle up the frameworks it creates and reveal the inadequacies of generalizations.

\section{The Interrelatedness of Law and Literature}

Legal judgment is composed of literary judgment. In the trial, both attorneys script different narratives from the same set of facts. While the prosecutor parallels Ivan's posture of abstract judgment, the defense attorney parallels Alyosha's posture of individuated judgment. "[T]he Russian courts exist not only for punishment," Fetyukovich declares, urging the need for mercy and understanding, "but also for the salvation of the ruined man! Let other nations have the letter and punishment, we have the spirit and meaning." (BK 748) Thus within the law (represented by the trial) exist postures of both abstract and individuated judgment. The trial of Dimitri illustrates that the law, like everything else in the novel, is a dialogue.

As with the rest of the novel, Dostoyevsky carries his obsession with storytelling into Dimitri's trial. The trial is an artistic creation, a struggle between narratives in order to reconstruct the past. Dostoyevsky frequently portrays the trial as a manufactured event. When Captain Snegiryov's testifies to something unexpectedly, the narrator notes: "The effect prepared by the prosecutor did not come off at all." (BK 669) Fetyukovich is dubbed "the great magician," (BK 670) and the attention of the court is frequently focused on how he will perform. The prosecutor and defense attorney both accuse each other of crafting fictions. "The Prosecution liked its own novel," Fetyukovich declares, "...what if you have created a novel around quite a different person? That's just it, you have created a different person!" (731-732) The prosecutor counters in his rebuttal: "We are reproached with having invented all sorts of novels. But what has the defense attorney offered if not a novel upon novel?" (BK 748) Thus, the law, internally, is a dialogue--ambivalent, turbulent, dynamic.

In addition to confronting other narratives in a dialectical relationship, all narratives have an internal polyphony as well. Each narrative within the trial is itself divided, for within each exists the possibility for multiple interpretations. The narrator constantly describes the public's conflicting impressions of the trial. The trial returns to the theme of psychology (which Ivan believes leads to the conclusion that there is no one to blame) to show that through multiple interpretations, it can lead to almost any conclusion. For example, the medical experts cannot agree as to Dimitri's mental state. "But psychology, gentlemen, though a profound thing, is still like a stick with two ends" Fetyukovich asserts, "...One can draw whatever conclusions one likes from it. It all depends on whose hands it is in." (BK 727-728) In fact, Fetyukovich illustrates how everything can be deconstructed, how nothing is exact and irrefutable. While Ippolit uses psychology to prove the crime, ${ }^{84}$ Fetyukovich

${ }^{82}$ See Gary Morson, "Verbal Pollution" in The Brothers Karamazov, in Modern Critical InTERPRETATIONS: Fyodor Dostoevsky's THE BRothers Karamazov, Harold Bloom ed., (New York: Chelsea House, 1988), pp. 85, 94.

${ }^{83}$ One of the best examples of this is when Don Quixote and Sancho Panza critique their own portrayal by the earlier part of the novel. See Miguel De Cervantes, Don QuiXote, J.M. Cohen, trans., (London: Penguin Books, Ltd., 1950), pp. 484-496.

${ }^{84}$ Ironically, Ippolit, while sharing a similar posture as Ivan, uses psychology to establish a crime 
devotes a substantial portion of his speech trying to deconstruct the very crime of parricide. Using logic and reason in a similar fashion as Ivan, Fetyukovich intimates the position that there is no crime, that everything is permitted.

Dostoyevsky thus sees law, although capable of error, as not barren of the individuated grace of literature, for the law itself is an artistic creation, composed not solely by legal judgment but by literary judgment as well. The law is a composition shaped through a series of judgments made by the stylists of the law, each with a posture of how to judge. Thus, while law is distinct from literature, more constrained in its ability to individuate, the law is simultaneously conjoined to literature. Law and literature meld into each other, for they both participate in the common activity of judging.

Although legal and literary postures of judgment must exist at a certain distance from the world they act upon, they are also inextricably linked to the world as well. The Brothers Karamazov illustrates that narratives are not just abstractions from reality, but are an integral part of reality. The novel emphasizes the interconnectedness of narratives, how we form ourselves and each other through narratives. We are constantly revising and modifying our life stories, for our personal narratives are incomplete and changing. ${ }^{85}$ Like our life stories, legal stories are also incomplete. The novel itself exists as a mosaic of multiple voices, dialogues, and narratives. The narrator often describes events not just by personal account, but by piecing together various gossip, rumors, and notes from others. Ivan's powerful arguments exist as a collage of newspaper articles and fictional stories. Zosima's story is composed by the stories of others. The novel contains stories within stories, narratives told and retold within other narratives. Zosima retells the visitor's narrative, but this is contained in Alyosha's retelling of Zosima's stories, all of which is contained in the narrator's retelling of the events of the novel. Thus, Dostoyevsky illustrates that our stories--even our most personal ones--are all interconnected, constructed out of each other.

The interconnectedness of narratives parallels the interconnectedness of all of the characters' postures of judgment. Legal and literary narratives are engendered through postures of judgment, and as a result, are inextricably related. In fact, the trial, like the novel, consists of a patchwork of stories, overlapping, contradictory, fragmented, incomplete. These stories are told and retold by different witnesses and attorneys. Moreover, rules and standards are not opposite types of law, but are often in constant motion, gravitating toward each other. A general and inflexible rule can be riddled with exceptions, evasions, and manipulations. In this way, a rule can become more individuated until it is as unstable as a standard. ${ }^{86} \mathrm{~A}$ standard can be applied in a certain manner for so long that it becomes fossilized into the equivalent of a rule.

Understanding both law and literature as a range of postures of judgment, we can better understand the relationship between them, recognize the literature within the law and the law within literature. The Brothers Karamazov needs both legal and literary postures of judgment for completeness, illustrating that law and literature are both integral components of each other. For Dostoyevsky, reality and representation are contradictory yet continuous. This same relationship exists between law and literature, between law and life, between literature

rather than to argue that there is no crime and that everything is permitted.

${ }^{85}$ See James Boyd White, Heracles' Bow (Madison: University of Wisconsin Press, 1985), pp. 169-170.

${ }^{86}$ See Duncan Kennedy, "Form and Substance in Private Law Adjudication," 89 Harvard Law Review 1685, 1701 (1986). 
and life. Dostoyevsky presents us with a new way to view the connections between law and literature--not literature as an ethical commentary about law, not law as a literary text, but law and literature as linked by the common activity of judging, as essential components of the world they judge.

\section{B. Evaluating Postures}

Seen through Dostoyevsky's fractured shifting lens, judging is divided, dynamic, contradictory, and interconnected. Saying that judging can never resolve the tension between abstraction and individuation does not mean that we can no longer evaluate various styles of judging. In fact, it is how decisionmakers engage in the struggle with this tension that can provide a basis for normative conclusions about judging. These normative claims will not amount to a complete systematic theory about judgment; rather, we can glean flashes of insight and wisdom by examining literature and its engagement with the tension.

\section{Timidity and Turbulence}

Ivan restlessly searches for a location of repose. Dissatisfied with every position with which to judge others, Ivan refuses to assume any posture of judgment. Ivan remains tentative about adopting a posture of purely abstract judgment, so he flees to the world of fiction (the Grand Inquisitor narrative) where he can adopt this posture without experiencing its consequences. In fact, Ivan's reaction to the wrongdoing and suffering of the world is to flee, to escape.

Zosima observes Ivan's plight: "The question is not resolved in you, and there lies your great grief, for it urgently demands resolution." (BK 70) Ivan asks: "But can it be resolved in myself? Resolved in a positive way?" (BK 70) Zosima answers: "Even if it cannot be resolved in a positive way, it will never be resolved in the negative way either." (BK 70) No posture can ever be resolved, but there are positions of less turbulence and timidity. Ivan seeks resolution or tries to escape.

Dostoyevsky illustrates the problems of Ivan's posture not by providing an academic treatise against it, but by placing Ivan's posture in dialogue with other postures. Ivan's overthrow of God, in which everything is permitted (absolute freedom of the human will) and his solution posited by Grand Inquisitor (authoritarian rule by human gods) are overthrown when his father is murdered and his innocent brother Dimitri is charged with the crime. In his confession to Ivan, Smerdyakov indicts Ivan: "...still you are guilty of everything, sir, because you knew about the murder, and you told me to kill him, sir, and, knowing everything, you left." (BK 627) Ivan becomes horrified when he witnesses his ideas implemented by Smerdyakov, when he sees his ideas escape from the realm of literary fiction and enter into the world of legal action. No longer an abstract philosophical theory, Ivan's ideas have led to terrible consequences: he has permitted the murder of his own father. Realizing that his innocent brother will be punished unjustly, Ivan sees the grave shortcomings of his posture of abstract judgment. Ivan, unable to accept the culmination of his rebellion, falls ill and suffers from hallucinations of Satan, who mockingly argues Ivan's own ideas. Forced to hear his own theories, Ivan eventually covers his ears, no longer able to listen. His grandiose theory of rebellion self-destructs, incapable of succeeding in practice. Alyosha's posture, while difficult, is still maintainable. It gets strengthened throughout the novel. Ivan's posture is too unsettled, too divided to survive. His judgments of God, of humanity, and of himself are inadequate when confronted with the test of life. 


\section{Formalism and False Repose}

Ivan mistakenly believes that he can flee from the struggle by distancing himself. Abstract rules can provide the illusion of a haven in which judges can pretend to escape from the struggle of judgment. Rigid rules can reduce personal responsibility for choice, allowing judges to claim to be bound by the law. Robert Cover described this attempt to hide behind a rule as a retreat to a mechanistic formalism: "However, the prevailing course of action of the antislavery judge was to speak in conclusory terms of the obligation to apply 'the law and the law alone'; of the obligation to refrain from considering conscience, natural right, or justice." 87 Judge Jerome Frank noted that the judges who are most prejudiced by their emotions are often those "who elaborately wrap about themselves the pretense of merely discovering and carrying out existing rules." ${ }^{18}$ However, no matter where a decision maker stands, she can never escape the tension between abstraction and individuation. In contrast to Justice Scalia's view, rules can be more arbitrary than unfettered judicial discretion. A rule can be under- or over-inclusive, leading to uncertainty and arbitrariness. ${ }^{89}$ There is simply no way to avoid discretion. Rules can shift discretion--from the rule- applier to the rule-maker, from one legal actor to another. Discretion does not disappear; the critical elements most influenced by rules concern who shall decide and the location and distance of the decisionmakers. For example, Daniel Freed discusses how the sentencing guidelines, designed to curb the discretion of judges in sentencing, merely transferred much of that discretion to prosecutors, who could alter the charges brought in order to influence the sentence. ${ }^{90}$

The key difference is attitude. When decisionmakers adopt a certain posture in order to flee from the tension, to diminish their sense of responsibility, they are neglecting their duties to decide the case in the best interests of the parties involved and are indulging themselves instead. Lon Fuller presents the most stark example of this tendency in The Case of the Speluncean Explorers. ${ }^{91}$ The case involves a scenario in which several cave explorers, trapped for weeks in a cave, killed and ate one of their party to survive. They are charged with murder under a strict statute and the justices are forced to decide whether to make a special exception. One judge holds that the defendants are innocent because, looking to the spirit of the law, it could not possibly have been designed to apply to them. ${ }^{92}$ Another judge defers, using the language of judicial restraint. Judges must be faithful to the law, and the defendants must be held guilty. ${ }^{93}$ Various other judges take different sides, and the court is deadlocked. Judge Tatting, the swing vote, cannot resolve the difficulty, and withdraws from the case. ${ }^{94}$ However, due to the tie vote, the conviction will be affirmed. Judge Tatting, in refusing to make a choice, did indeed make a choice: his actions resulted in the convictions of the defendants. Perhaps this was not his desired outcome for the case, but personally, he could argue to himself that he was not responsible. Judge Calabresi refers to a similar

\footnotetext{
${ }^{87}$ See Robert Cover, Justice Accused (New Haven: Yale University Press, 1975), p. 233.

88 Jerome Frank, LAW AND THE Modern Mind (1930; Gloucester: Anchor Books, 1963), p. 134 (emphasis in original).

${ }^{89}$ See Kennedy, supra note 86 at 1689.

${ }^{90}$ Daniel J. Freed, "Federal Sentencing in the Wake of the Guidelines: Unacceptable Limits on the Discretion of Sentences," 101 Yale Law Journal 1681, 1742 (1992).

${ }^{91}$ Lon L. Fuller, "The Case of the Speluncean Explorers," 62 Harvard Law Review 616 (1949).

${ }^{92} I d$., at 624

${ }^{93} I d$. at 633.

${ }^{94} I d$., at 631 .
} 
approach in his book on difficult allocative decisions; he refers to it as the "customary approach," the choice not to choose. ${ }^{95}$

In The Brothers Karamazov, Dostoyevsky reveals the critical defects in these types of postures: both lack the courage to struggle with the tension between abstraction and individuation. Both postures avoid rather than engage the problems.

We live in a world of action. Our postures--whether we engage the world or whether we attempt to flee--can never bring us the transcendent reconciliation we desire. Like Ivan, we can flee constantly, but as Dostoyevsky illustrates, Ivan's fleeing results in terrible consequences. He leaves town when he is needed most at his father's house, when it seems likely that his father will be murdered. In the end, he finally accepts responsibility for his actions; he understands that his flight and retreat were the equivalent of action. Fuller's example teaches us that legal formalism sometimes provides more hiding places than it does opportunities for a posture of responsible choice.

\section{Engagement and The Courage to Struggle}

In contrast to these postures, Dostoyevsky presents Alyosha and Zosima. Both engage the world rather than attempt to flee. In a world in which escape is self-delusion, the better postures are Alyosha's and Zosima's, who engage the world honestly, courageously, and compassionately. Alyosha must exert great fortitude to maintain his posture. What makes him Dostoyevsky's hero is his courage in facing his inner struggle. Alyosha constantly struggles with the danger of being seduced toward Ivan's posture of judgment. Early in the novel, Alyosha expresses doubt in God's existence. "[M]aybe," the words slip mysteriously from his mouth, "I don't even believe in God." (BK 220) Later, when Ivan tells Alyosha the story of the general who ordered his dogs to tear an innocent child to pieces, Alyosha, with a "twisted smile," expresses a desire to shoot the general. (BK 243) When the reputation of Zosima is ruined due to an odor emanating from his deceased body, Alyosha becomes enraged and thirsts for justice. He parrots Ivan's words rejecting the world of God and almost succumbs to debauchery. But after Alyosha is saved, he falls to the earth, kissing and embracing it. Alyosha's actions represent a return from his flight into the distant world of Ivan's abstractions, a return to the concrete: "He fell to the earth a weak youth and rose up a fighter, steadfast for the rest of his life." (BK 363) Paradoxically, a collapse in utter weakness becomes an elevation in strength and triumph.

This paradox of strength through weakness is paralleled in Dostoyevsky's style. Saul Bellow praises the fact that Dostoyevksy supplies Ivan's arguments with so much vigor and strength, even though he wishes to refute them:

Dostoyevsky wrote to one of his correspondents that he must now attempt, through Father Zosima, to answer Ivan's arguments. But he has in advance all but devastated his own position. This, I think, is the greatest achievement possible in a novel of ideas. It becomes art when the views most opposite to the author's own are allowed to exist in full strength. Without this a novel of ideas is mere self-indulgence, and didacticism is simply axe-grinding. The opposites must be free to range themselves against each other, and they must be passionately expressed on both sides. ${ }^{96}$

${ }^{95}$ CALABRESI AND BoBBitT, supra note 61 at $44-49$.

${ }^{96}$ Saul Bellow, "Where Do We Go From Here: The Future of Modern Fiction," Michigan Quarterly Review 33 (1982). 
There is no ultimate resting place, no comfortable position to opt out of wrestling with abstraction and individuation, only the illusion of such a position. Ivan creates such an illusion in his Inquisitor parable, yet it only masks his inner turmoil, which finally erupts at the end of the novel. The Brothers Karamazov ends with each character still unresolved. Everyone, even Alyosha, will have to struggle internally as well as externally. Thus, Dostoyevsky establishes a relationship between recognition and method: decisionmakers must recognize that there are no stable postures, and that they must learn to accept the tensions in order to navigate them more effectively. Literature can aid in the recognition, in the deepening of our vision, in the understanding that law is not a distinct discipline but is continuous with literature and with life.

\section{Conclusion}

Ronald Dworkin's principled account of judging strictly dichotomizes legal arguments and facts, viewing facts as separate from the law and as relatively unimportant for a robust theory of judging. I have argued that jurisprudence, in order to make progress in understanding the question of fit, must focus less exclusively on legal propositions and more upon the relationship between law and fact. The notion of postures provides an appropriate depiction of the complex interactions between general legal propositions and the concrete facts of particular cases. The question of fit is not reconciled merely by analyzing prior legal decisions and then deducing a "right answer" from a web of principles. Rather, judging is an activity that is improved with practice, courage, and creativity. "[L]aw is an art" writes Charles Black. ${ }^{97}$ Black points out that the unpredictability and imperfections in law are what enable the art of law to be practiced in interesting and creative ways. ${ }^{98}$ For Black, the constraints of law are not always detriments. He notes that music is made possible by its limitation and that jazz is a combination of improvisation and conservativity in tonality and harmony. ${ }^{99}$ In Robert Browning's poem, "Andrea Del Sarto," Andrea, known as the faultless painter, fails to achieve true greatness as an artist because he paints too precisely. Andrea realizes that the imperfections in an artwork's depiction of reality are often the elements that make it a masterpiece. Thus, the necessary abstraction of art is not always a failure to capture reality but can be seen as a triumph of artistic expression. Literature, in addition to music, is a way to add meaning to life through limitation, by skimming only a few details off the richness of experience. "The power to guess the unseen from the seen," wrote Henry James, "to trace the implications of things, to judge the whole piece by the pattern, the condition of feeling life in general so completely that you are well on your way to knowing any particular corner of it--this cluster of gifts may almost be said to constitute experience." ${ }^{100}$ Art shows us creative ways to play with the tension between the general and the particular. "Art," James continued, "is essentially selection, but it is a selection whose main care is to be typical, to be inclusive." ${ }^{101}$ "Artistic" decisions depend upon a posture of judgment, upon an evolving artistic style of encountering the world, a style which exists embodied within its creator.

${ }^{97}$ Charles Black, JR., The Humane Imagination (Woodbridge: Ox Bow Press, 1986), p. 17.

${ }^{98} I d$., at 21.

${ }^{99} \mathrm{Id}$., at 30-32.

${ }^{100}$ Henry James, "The Art of Fiction," in Myth And Method: Modern TheOries of Fiction, James E. Miller, ed. (Ann Arbor: Books on Demand, 1960), p. 35.

${ }^{101} I d$., at 39 . 
Law is an art because it is composed from various postures of judgment. Law is an ambivalent struggle, a composition of many voices. Its need for abstraction, uniformity, and distance conflicts with doing justice to each person in each instance. Literature can teach us new ways of judging, both in its form (for art is composed through judgment) and in its content. As illustrated in this essay, The Brothers Karamazov teaches us how to recognize and cope with these tensions and reveals to us the successes and failures of various postures of judgment. The successful solutions are not ideological but artistic in character--creative and courageous postures that juggle the tensions between abstraction and individuation. 